\title{
„INCYDENT” W STOPNICY 9 WRZEŚNIA 1939 ROKU - MIĘDZY ZBRODNIĄ SĄDOWĄ A EGZEKUCJĄ
}

\begin{abstract}
Abstrakt: Artykuł traktuje o jednym z epizodów walk Armii „Kraków” we wrześniu 1939 r. Wojska agresora popełniały na ziemiach polskich liczne zbrodnie wojenne, ale rażącego złamania prawa wojennego dopuściła się także strona polska. Artykuł prezentuje jeden taki dobrze udokumentowany przypadek - małopolskiego miasteczka Stopnica.
\end{abstract}

Słowa kluczowe: wojna obronna 1939 r., zbrodnia wojenna, Stopnica, Wojsko Polskie, Wehrmacht, płk Stanisław Kalabiński.
Abstract: The article deals with one of the episodes of the fight put up by the "Kraków" Army in September 1939. The German troops committed many war crimes in the Polish lands, but also the Polish side was responsible for gross violations of martial law. The article presents one of such cases a well-documented case of the town of Stopnica in Little Poland.

Keywords: defensive war of 1939, war crime, Stopnica, Polish Army, Wehrmacht, Col. Stanisław Kalabiński.

\section{Wstęp}

Tytułowy „incydent” (terminu tego używać będę w ślad za Janem Przemszą-Zielińskim) ${ }^{1}$ miał miejsce 9 września 1939 r., podczas odwrotowych bojów toczonych przez działającą w składzie Armii „Kraków” 55. Dywizję Piechoty (DP). Ta wielka jednostka, dowodzona przez płk. Stanisława Kalabińskiego, już od pierwszych godzin działań wojennych znajdowała się bezustannie w ogniu walk. Owego 9 września żołnierze dywizji, konkretnie 201. Pułku Piechoty (pp) ppłk. Władysława Adamczyka, otrzymali

${ }^{1}$ J. Przemsza-Zieliński, Jeden z tysiąca Zagłębiaków. Rzecz o pułkowniku Stanisławie Kalabińskim, ostatnim dowódcy śląsko-dąbrowskiej Obrony Narodowej, Sosnowiec 1998, s. $164-166$. 
zadanie utrzymania miasteczka Stopnica. W Stopnicy znajdowały się nie tylko oddziały ppłk. Adamczyka, lecz również sztaby: płk. Kalabińskiego, gen. Jana Sadowskiego, dowódcy Grupy Operacyjnej (GO) „Śląsk”, oraz gen. Antoniego Szyllinga, dowódcy Armii „Kraków”.

To, co zaszło wówczas w miasteczku, a co określane jest właśnie mianem „incydentu w Stopnicy”, jak dotychczas najpełniej przedstawił Przemsza-Zieliński ${ }^{2}$ „Najpełniej” nie oznacza jednak, że zarazem najbardziej wiarygodnie. Do obrazu tego dodać można bowiem informacje, które radykalnie zmieniają wersję wydarzeń zaprezentowaną przez tego nieżyjącego już historyka, a nawet więcej - stawiają pod znakiem zapytania jego intencje.

\section{Polskie opisy powojenne}

Rozpocznijmy od powojennych polskich relacji; licznych, do tego niemalże jednobrzmiących. Jeden z najwyższych stopniem spośród obecnych wówczas w Stopnicy wojskowych, czyli gen. Sadowski, pisał:

W samej Stopnicy powstaje strzelanina. To jakiś niemiecki autobus wojskowy, wiozący 30 żołnierzy niemieckich, jadących ze Staszowa, mylnie poinformowany przez swe dowództwo, że Stopnica jest już zajęta przez oddziały niemieckie, wjechał na sam rynek. Nie dostrzegł przy wjeździe do Stopnicy dobrze zamaskowanej naszej obrony, a nie został przez nią zatrzymany, aby go w mieście pochwycić. Na rynku wywiązuje się krótka walka. Niemcy rzucają granaty ręczne i rozbiegają się po najbliższych domach, w których się bronią. Opór ich zostaje szybko zlikwidowany. Część dostaje się do niewoli ${ }^{3}$.

Również obecny wówczas na miejscu ppłk dypl. Jan Rzepecki tak zrelacjonował to wydarzenie:

W kilka chwil potem zaszedł tu wypadek niezwykły. Nagle ukazał się na szosie czerwony autobus, podobny do ewakuowanych z Krakowa, i pełnym gazem wjechał do miasteczka. Dopiero kiedy mijał działo, obsługa zauważyła, że był pełen Niemców. Prawdopodobnie Niemcy z północy wzięli pożary za sygnał, że miasteczko jest już zajęte natarciem od zachodu i wysłali ten

2 Ibidem, s. 191-203.

${ }^{3}$ Cyt. za: ibidem, s. 165. Relacja ta znajduje się również w zbiorach Instytutu Polskiego i Muzeum im. gen. Władysława Sikorskiego (dalej: IPMS) w Londynie. IPMS, B.I.52.A, J. Sadowski, Grupa Operacyjna Śląsk: pr[zy]gotowanie i udział w kampanii 1939 roku. Relacja dowódcy Grupy, 1946 r., b.pag. 
oddział bez żadnego ubezpieczenia. W rynku wybuchła strzelanina. Podobno załogę autobusu w połowie wybito, w połowie wzięto do niewoli ${ }^{4}$.

O incydencie stopnickim napomknął też Władysław Steblik, we wrześniu 1939 r. mjr dypl. w sztabie armii. Według niego wyglądał on następująco:

Panowała tu w tej chwili zupełna cisza. Nagle wynurzył się z tych lasów czerwony autobus i pędząc szosą z błyskawiczną szybkością wjechał do miasteczka. Załoga czatującego przy wlocie szosy działka przeciwpancernego nie strzeliła do autobusu chyba dlatego, że był podobny do autobusów ewakuowanych z Krakowa i dopiero gdy ją mijał, zauważyła, że są w nim żołnierze niemieccy. Za chwilę wybuchła jednak w miasteczku gwałtowna strzelanina. Po dołączeniu wkrótce potem sztabu Grupy Operacyjnej opowiadano nam, że gdy autobus wjechał na rynek, Niemcy otworzyli z jego okien ogień, pod którego osłoną usiłowali się rozbiec w kierunku zabudowań, na co zbierające się do wymarszu oddziały zareagowały spontanicznymi strzałami. Niemal wszyscy Niemcy polegli ${ }^{5}$.

Na tym tle raczej wstrzemięźliwie prezentują się wspomnienia ppłk. Adamczyka. W swych wydanych dopiero w 1970 r. pamiętnikach pisał on:

Dowódca I baonu znów melduje, że schwytał 15 jeńców, którzy zbyt blisko podeszli do zabudowań. [--] wkrótce też nadeszła wiadomość o wypędzeniu Niemców z zabudowań w zachodniej części miasteczka. Złapano tam również kilkunastu jeńców. [--] Przyprowadzają jeńców na plac przed kościołem. Jest ich ponad trzydziestu. Kazałem ich odprowadzić do dowództwa dywizji. Nie chcę z nimi rozmawiać. Czego się zresztą dowiem? Że są wszędzie koło nas? W chwilę później przyprowadzono również kilkunastu

${ }^{4}$ J. Rzepecki, Wspomnienia i przyczynki historyczne, wyd. 2, Warszawa 1983, s. 131132. Zwróćmy uwagę na zabieg relata refero. W przypisie Rzepecki dodatkowo wyjaśnia: „Epilog tego incydentu był tragiczny. Wybitym oddziałem okazała się orkiestra. W związku z tym dowódcy 55. dywizji, pułkownikowi Stanisławowi Kalabińskiemu, już w niewoli wytoczyli Niemcy sprawę o złamanie Konwencji Genewskiej (wybicie oddziału bezbronnego) przez jego żołnierzy; został skazany na śmierć i rozstrzelany", ibidem, s. 132.

5 W. Steblik, Armia „Kraków” 1939, Warszawa 1975, s. 383. Również i tu autor zastrzega, iż prezentowane informacje pochodzą z drugiej ręki. Fragment ten opatrzony jest ponadto obszernym przypisem, przedstawiającym dalsze losy płk. Kalabińskiego (zaczynającym się od słów „Incydent ten, jak dowiedzieliśmy się po wojnie, miał tragiczne następstwa”). Niemcy bowiem „zaraz po zakończeniu walki z Armią «Kraków» zaczęli poszukiwać oficera «winnego wymordowania» tej rzekomo bezbronnej orkiestry, dopatrując się go głównie w dowódcy 55. dywizji piechoty rez., płk. S. Kalabińskim", ibidem, s. 423-424. 
jeńców z niemieckiej orkiestry, schwytanych u wejścia do wsi przez żołnierzy z I batalionu. Odeszli również do dowództwa dywizji ${ }^{6}$.

Z przedstawionych opisów wynikałoby zatem jednoznacznie, że poruszający się cywilnym autobusem członkowie niemieckiej orkiestry wojskowej, po niespodziewanym dostaniu się w sam środek polskich oddziałów, chwycili za broń; jakaś część z nich zdołała wydostać się z pojazdu i schronić w przyległych zabudowaniach, skąd to prowadzić mieli ogień. Po krótkiej walce część poległa, reszta zaś dostała się do niewoli. W takim ujęciu cały incydent nie niósłby ze sobą niczego szczególnego; byłaby to jedna z wielu potyczek, w jakie obfitowały odwrotowe walki Armii „Kraków". Taką też wersję wydarzeń przyjął czołowy dziejopis wojennego wysiłku pułków GO „Śląsk”, czyli właśnie Przemsza-Zieliński

Tymczasem jeszcze w 1939 r. strona niemiecka zaprezentowała skrajnie odmienną interpretację tych wydarzeń.

\section{Czynności dochodzeniowe radcy Joachima Schölza}

Już w połowie września 1939 r. pojawił się w Krakowie radca rządowy Joachim Schölz, urzędnik wojskowego wymiaru sprawiedliwości, działający z ramienia afiliowanej przy Naczelnym Dowództwie Wehrmachtu

${ }^{6}$ W. Adamczyk, Przeciw nawale. Rok 1939. Pamiętnik dowódcy 201. pułku piechoty, Warszawa 1970, s. 162-163. Relacja ta zasługuje na baczniejszą uwagę; oto dobrze zorientowany w tworzonej przez swoich towarzyszy broni literaturze przedmiotu Adamczyk nie zdecydował się na obszerniejszą wzmiankę o całym incydencie. Nie napomknął też o walce, mającej poprzedzać wzięcie orkiestry do niewoli (choć wskazał odpowiedzialny za to oddział, czyli 1. batalion 201. pp, dowodzony wówczas przez kpt. Pawła Blewa), wyraźnie przy tym zaznaczając, iż kontakt z jeńcami (nie tylko tymi z orkiestry, ale i wziętymi do niewoli wcześniej) stracił po odesłaniu ich do sztabu dywizji, zatem w ręce płk. Kalabińskiego. Wreszcie - w swoim opisie Adamczyk wyraźnie bagatelizuje to wydarzenie, nie przydając spotkaniu z jeńcami żadnego znaczenia. Tymczasem jest to jedyna w ogóle w jego wspomnieniach wzmianka o jakichkolwiek jeńcach!

7 Zwrócić należy uwagę na konkluzję, którą Przemsza-Zieliński zamyka swą prezentację wspomnień obecnych w Stopnicy polskich oficerów. Po przytoczeniu stosownych fragmentów pisze: „I tyle... Incydent z autobusem w ogóle wówczas [wyróżnienie G.B.] nie był rozpatrywany jako wydarzenie jakiejś szczególnej wagi - traktowano go powszechnie jako nieistotny fragment wydarzeń tego dnia. Były ważniejsze sprawy na głowie dowódców...", J. Przemsza-Zieliński, Jeden z tysiąca Zagłębiaków, s. 165-166. Zdumiewające słowa; wynika z nich, że Przemsza-Zieliński traktuje cytowane przez siebie powojenne wspomnienia jako rodzaj dzienników, oddających rzeczywistość uchwyconą w niemalże fotograficznym kadrze. Wszystko zdaje się wskazywać, iż ów niezręczny zabieg był przezeń zamierzony. 
Placówki Dochodzeniowej ds. Naruszeń Prawa Międzynarodowego. $\mathrm{W}$ dniach 17 i 18 tego miesiąca przesłuchał on czterech przebywających w miejscowym lazarecie niemieckich żołnierzy: Kurta Lemsera i Helmuta Schloerba, obydwu z orkiestry 15. pułku pancernego (ppanc), oraz Willi'ego Fischera z 2. pułku strzelców i Gerharda Müllera z 3. ppanc (obydwa te pułki wchodziły w skład 2. Dywizji Pancernej [DPanc.]). Dodatkowo, 19 września tego roku radca Schölz pojawił się również w będącym garnizonem 15. ppanc Żaganiu, gdzie w tej samej sprawie przesłuchał innego członka orkiestry, Gerharda Kiwusa ${ }^{8}$. Wszystkie protokoły kończyły się informacją o złożeniu przez przesłuchiwanego przyrzeczenia: „Przysięgam przed Bogiem, Wszechmocnym i Wszechwiedzącym, że zeznałem szczerą prawdę według swojej najlepszej wiedzy, niczego nie przemilczając. Tak mi dopomóż Bóg!"9.

Dwóch spośród przesłuchiwanych (Fischer oraz Müller) dostało się do niewoli 7, względnie 8 września, w trakcie działań bojowych w rejonie miejscowości Radłów. Następnie, w grupie kilkunastu innych jeńców prowadzeni byli w głąb kraju, by rankiem 9 września znaleźć się w Stopnicy ${ }^{10}$.

Trzej pozostali (Lemser, Schloerb oraz Kiwus) byli natomiast, jako członkowie orkiestry 15. ppanc, pasażerami pamiętnego autobusu. Jak podaje pierwszy z nich, kierowana przez kapelmistrza feldfebla Heinricha Copa orkiestra liczyć miała 31 osób ${ }^{11}$. Spójrzmy, jak z ich perspektywy wyglądał moment wjazdu do Stopnicy oraz dostanie się do polskiej niewoli. Lemser zeznał:

W dniu 9 września 1939 r. nasza orkiestra skierowana została z frontu do Żagania, ponieważ autobus, którym podróżowaliśmy, nie był w stanie nadążyć za szybko posuwającymi się naprzód oddziałami. [--] Kiedy dojechaliśmy na skraj miejscowości, która, jak pamiętam, nazywa się Stopnica, za zakrętem drogi ujrzeliśmy nagle polskie wojsko. Była to ciężka i lekka artyleria, piechota i kawaleria, wszystko przemieszane. Sądzę, że była to brygada kawalerii. Kiedy po raz pierwszy zobaczyliśmy Polaków, oddaleni byli oni od nas jedynie o około 20 metrów, wobec czego nasz kierowca nie był w stanie zawrócić i spróbował szybko przejechać obok nich.

${ }^{8}$ Bundesarchiv-Militararchiv Freiburg (Federalne Archiwum Wojskowe we Fryburgu; dalej: BAMA Freiburg), RW 2-48, k. 131-145.

9 „Ich schwöre bei Gott, dem Allmächtigen und Allwissenden, daß ich nach bestem Wissen die reine Wahrheit gesagt und nichts verschwiegen habe, so wahr mir Gott helfe", BAMA Freiburg, RW 2-48, k. 133, 136, 139, 142 i 145.

10 BAMA Freiburg, RW 2-48, Protokół przesłuchania W. Fischera, 18 IX 1939, k. 137138; ibidem, Protokół przesłuchania G. Müllera, 18 IX 1939, k. 140-141.

11 BAMA Freiburg, RW 2-48, Protokół przesłuchania K. Lemsera, 17 IX 1939, k. 131. 
Polacy byli początkowo zaskoczeni, szybko jednak zaczęli ostrzeliwać nasz pojazd z karabinów oraz jakiegoś rodzaju dział przeciwpancernych. Odpowiedzieliśmy ogniem $\mathrm{z}$ naszych pistoletów. Otrzymałem postrzał $\mathrm{w}$ ramię oraz dwa odłamki w udo, po czym wraz z tymi spośród kolegów, którzy nie byli ciężej ranni, wyskoczyłem z pojazdu. Chcieliśmy schować się w jakimś domu. Ledwie zdążyliśmy tam wbiec, kiedy oni byli już za nami, rzucając granaty ręczne. Musieliśmy wobec tego podnieść ręce i poddać się ${ }^{12}$.

Kolejny z członków orkiestry, Helmut Schloerb, opisuje te okoliczności następująco:

W sobotę 9 września nasza orkiestra wycofana została z frontu [--] do domu, jako że nasz autobus był zbyt ociężały i opóźniał marsz oddziałów. Po około półgodzinnej jeździe przybyliśmy do wsi Stopnica. Nagle zobaczyliśmy Polaków. Nim zorientowaliśmy się, że są to polscy żołnierze, byliśmy już niemalże przy nich. Kierowca próbował zatem przejechać obok nich. Uderzył przy tym w ścianę jakiegoś domu. Natychmiast wycofał pojazd i zdołał ujechać jeszcze kawałek, po czym autobus się zatrzymał. W tym samym czasie otwarto do nas ogień z karabinów ręcznych i maszynowych. W tylną część pojazdu uderzył armatni granat, prawdopodobnie o kalibrze $47 \mathrm{~mm}$. Odpowiedzieliśmy ogniem z naszych pistoletów. Ja wystrzelałem cały magazynek. Potem Polacy wyprowadzili nas z pojazdu ${ }^{13}$.

12 „Am 9. September 1939 wurde unser Musikkorps von der Front nach Sagan in Marsch gesetzt, weil der Omnibus, in dem wir fuhren, den schnellen Vormarsch nicht mitmachen konnte. [--] Als wir auf der Heimfahrt an den Eingang eines Ortes kamen, der nach meiner Erinnerung Stopnica heißt, sahen wir plötzlich hinter einer Kurve polnisches Militär. Es war schwere und leichte Artillerie, Infanterie und Kavallerie, alles durcheinander. Ich nehme an, daß es eine Kavallerie-Brigade gewesen ist. Da die Polen, als wir sie zuerst sahen, nur noch etwa 20 Meter von uns entfernt waren, konnte unser Fahrer nicht mehr wenden und versuchte daher, schnell vorbeizufahren. Die Polen waren zuerst überrascht, schoßen dann aber mit Gewehren und einer Art Panzerabwehrgeschützen in unsern Wagen hinein. Wir erwiderten das Feuer mit unsern Pistolen. Ich bekam einen Armschuß und 2 Splitter in den Schenkel und sprang mit den Kameraden, die nicht schwerer verletzt waren, vom Wagen. Wir woll[t]en uns in einem Haus verstecken. Wir waren kaum rein, da waren sie schon hinter uns her und warfen Handgranaten. Wir mußten daher die Hände heben und uns gefangen geben", BAMA Freiburg, RW 2-48, Protokół przesłuchania K. Lemsera, 17 IX 1939, k. 131-132.

13 „Am Sonnabend, den 9. September wurde unser Musikkorps von der Front [--] nach Hause geschickt, weil unser Omnibus zu schwerfällig war und die Truppe behinderte. Als wir etwa $1 \frac{1}{2}$ Stunde gefahren waren, kamen wir in das Dorf Stopnica. Plötzlich sahen wir Polen. Als wir erkannten, daß es polnische Soldaten waren, waren wir schon dicht dran. Der Fahrer versuchte daher durchzufahren. Dabei fuhr er gegen eine Hauswand. Er fuhr sofort zurück und noch ein kurzes Stück vorwärts, dann blieb der Wagen stehen. Im gleichen Augenblick setzte Gewehr- und Maschinengewehrfeuer ein. In das Hinterteil des Wagens schlug eine Granate ein, die wohl ein Kaliber von 4,7 cm hatte. 
I wreszcie trzeci z przesłuchiwanych członków orkiestry, Gerhard Kiwus, pochodzący z Nowej Wsi Królewskiej (dziś w granicach Opola); znał on język polski, co okaże się nie bez znaczenia. Kiwus zeznał:

W sobotę 9 września nasza orkiestra skierowana została w drogę do Żagania [--] autobus, którym stale się poruszaliśmy, nie był w stanie nadążyć za szybko przemieszczającym się naprzód pułkiem. Po około godzinie drogi dojechaliśmy do Stopnicy. Przy wjeździe do miejscowości, za zakrętem zauważyliśmy nagle polskie wojsko. Była to artyleria i kawaleria. Zakładam, że chodziło tu o pobite elementy polskiej armii, które ukryły się w lasach, a teraz zamierzały się ponownie zebrać. Nasz kierowca w zdenerwowaniu uderzył w jakiś dom. Polacy otwarli do nas gwałtowny ogień, na który odpowiedzieliśmy ze swoich pistoletów. Ponieważ ostrzał był zbyt silny, wyskoczyliśmy z pojazdu, szukając ratunku w domach. Polacy rzucili się za nami. Broniłem się tak, jak tylko potrafiłem, aż do chwili wystrzelania całej amunicji. Potem musiałem się poddać ${ }^{14}$.

Do tego miejsca polskie i niemieckie relacje są na ogół zgodne; zasadnicza różnica leży w natężeniu walk toczonych przez członków orkiestry. Byli oni uzbrojeni, choć broń ta (pistolety) w warunkach frontowych służyć mogła raczej polepszeniu samopoczucia, aniżeli nawiązaniu równorzędnej walki. Brak za to wzmianek o użyciu przez pasażerów autobusu granatów ręcznych, których to prawdopodobnie nie mieli.

Tak czy inaczej, po krótkim starciu członkowie orkiestry dostali się do niewoli. Trudno powiedzieć, czy niektórzy z nich w trakcie tej wymiany strzałów polegli, jak sugerują to polskie narracje; w relacjach niemieckich nie ma na ten temat słowa (co oczywiście nie przesądza sprawy),

Wir erwiderten das Feuer mit unsern Pistolen. Ich verschoß ein Magazin. Dann holten uns die Polen aus dem Wagen", BAMA Freiburg, RW 2-48, Protokół przesłuchania H. Schloerba, 18 IX 1939, k. 134.

14 „Am Sonnabend, den 9. September 1939 wurde das Musikkorps in Richtung Sagan in Marsch gesetzt, weil unsere Instrumente zum Teil beschädigt waren und weil der Omnibus, in dem wir immer fuhren, bei dem schnellen Vormarsch unsers Regiments nicht mit kam. Als wir etwa 1 Stunde gefahren waren, kamen wir zur Ortschaft Stopnica. Am Ortseingang sahen wir plötzlich hinter einer Kurve polnisches Militär. Es war Artillerie und Kavallerie. Ich nehme an, daß es sich um die geschlagenen Teile der polnischen Armee gehandelt hat, die sich im Wald versteckt hatten und nun wieder im Sammeln begriffen waren. Unser Fahrer fuhr in der Aufregung gegen ein Haus. Die Polen eröffnet[en] ein heftiges Feuer, das wir mit unsern Pistolen erwiderten. Weil zu stark geschossen wurde, sprangen wir vom Wagen und suchten uns in die Häuser zu retten. Die Polen stürzten uns nach. Ich wehrte mich so gut ich konnte bis ich meine Munition verschossen hatte. Dann mußte ich mich ergeben", BAMA Freiburg, RW 2-48, Protokół przesłuchania G. Kiwusa, 19 IX 1939, k. 143. 
wspominane są za to odniesione wówczas rany. Następnie, już jako jeńcy dołączeni zostali do grupy innych, wcześniej wziętych do niewoli niemieckich żołnierzy. W tej właśnie grupie znajdowali się wspomniani Fischer i Müller.

Niemieccy świadkowie podnoszą też na ogół, że tuż po trafieniu do niewoli poddani zostali rewizji, w efekcie której odebrano im zarówno dokumenty, jak i większość osobistych przedmiotów, zwłaszcza tych cenniejszych, m.in. zegarki. Natomiast feldfebel Kiwus i podoficer Hampusch, jako najstarsi stopniem, zaprowadzeni zostali do jakiegoś polskiego oficera „z trzema gwiazdkami na kołnierzu” ${ }^{15}$. Lemser wspomina z kolei, że z całej orkiestry brak było feldfebla Rössnera (vel Rößnera) oraz podoficerów Langego i Markerta vel Merkerta. Pierwszy z całą pewnością zdołał ukryć się i uniknąć niewoli ${ }^{16}$.

Poza dwoma przesłuchiwanymi przez domniemanego kapitana, reszta jeńców doprowadzona została w pobliże cmentarza. Tam wyłączono z grupy od siedmiu do dziesięciu osób, ustawiając je w rzędzie twarzami do cmentarnego muru, jakoby z zamiarem rozstrzelania. Ciekawe, że gdy jeńcom dano („znakami”) do zrozumienia, że kilku z nich zostanie rozstrzelanych, jakiś starszy wiekiem polski żołnierz miał to następnie oznajmić po niemiecku dodając, iż osobiście nie pragnie tego, ale „większość jego kolegów pochodzi znad granicy i żywi wobec Niemców ogromną wściekłość"17. Przeszkodzić miał temu, co zgodnie podają wszyscy przesłuchiwani, nagły ostrzał Stopnicy przez niemiecką artylerię; polscy żołnierze, odstąpiwszy od zamiaru egzekucji poprowadzili jeńców na południe.

Eskorta liczyć miała, według różnych danych, od 50 do 80 żołnierzy, miałaby zatem w ówczesnych realiach wielkość plutonu. Byłaby ona przy tym mniej więcej dwukrotnie liczniejsza od prowadzonych jeńców; ci ostatni nieść mieli z sobą również rannych w walce ${ }^{18}$. Przynajmniej

15 „Unteroffizier Hampusch und ich wurden einem polnischen Offizier mit 3 Sternen am Kragen zur Vernehmung vorgeführt, weil wir die Ältesten der Abteilung waren”, BAMA Freiburg, RW 2-48, Protokół przesłuchania G. Kiwusa, 19 IX 1939, k. 143. Liczba gwiazdek wskazywałaby na stopień kapitana; oczywiście, ich umiejscowienie było inne.

16 BAMA Freiburg, RW 2-48, Protokół przesłuchania G. Kiwusa, 19 IX 1939, k. 145.

17 „Dann zählte man 8 Mann ab, die erschossen werden sollten, wie man uns durch Zeichen zu erkennen gab. Ein alter polnischer Soldat sagte uns auch, daß wir erschossen würden. Er fügte hinzu: «Er selbst wolle es nicht, aber die meisten seiner Kameraden seien von der Grenze und hätten eine große Wut auf die Deutschen»", BAMA Freiburg, RW 2-48, Protokół przesłuchania H. Schloerba, 18 IX 1939, k. 135. Wskazywałoby to, że eskortę tworzyli żołnierze któregoś z górnośląskich batalionów ON.

18 BAMA Freiburg, RW 2-48, Protokół przesłuchania H. Schloerba, 18 IX 1939, k. 135. 
niektórzy z niemieckich żołnierzy mieli już jakoby wówczas graniczące z pewnością podejrzenia co do czekającego ich losu ${ }^{19}$. Po trwającym trzy do czterech kwadransów marszu, około godziny 19.00-20.00 dotrzeć miano do samotnie stojącej zagrody z drewnianą stodołą ${ }^{20}$. Tu też miała się rozegrać zasadnicza scena, wokół której koncentruje się dotycząca „incydentu” narracja.

Pięciu niemieckich świadków na ogół zgodnie obrazuje przebieg późniejszych wydarzeń: na położonym przy zagrodzie polu jeńcy ustawić musieli się w dwuszeregu, zakładając ręce na kark ${ }^{21}$. Otaczający ich żołnierze eskorty na dany przez zwierzchników sygnał wycofywać zaczęli się za plecy konwojowanych, możliwie cicho repetując broń. Ci, którzy wciąż jeszcze znajdowali się wobec jeńców en face, nawoływani byli przez swoich kolegów słowami: „Chcecie dać się zastrzelić razem z nimi?”, co usłyszane zostało co najmniej przez znającego język polski Kiwusa, a może i innych ${ }^{22}$. Wszelkie wątpliwości rozwiać miał szczęk przeładowywanej broni, a następnie wystrzały.

Ogień prowadzić miano zarówno z karabinów ręcznych, jak i maszynowych; uwzględniając odległość, musiał być on morderczy. Schloerb uniknąć miał trafienia dlatego, że natychmiast padł na ziemię ${ }^{23}$. Część z jeńców na odgłos strzałów rzuciła się do ucieczki²4; zakładać można,

19 Znający język polski feldfebel Kiwus podawał, że już w Stopnicy podejrzewać miał, iż polscy żołnierze mają zamiar ich rozstrzelać; usłyszał jakoby jednego z nich mówiącego, iż jeńców należy wyprowadzić gdzieś poza miejscowość, gdzie nie będą mogli się im przyglądać cywile. BAMA Freiburg, RW 2-48, Protokół przesłuchania G. Kiwusa, 19 IX 1939, k. 144.

20 BAMA Freiburg, RW 2-48, Protokół przesłuchania H. Schloerba, 18 IX 1939, k. 135; ibidem, Protokół przesłuchania W. Fischera, 18 IX 1939, k. 138; ibidem, Protokół przesłuchania G. Müllera, 18 IX 1939, k. 141.

${ }^{21}$ BAMA Freiburg, RW 2-48, Protokół przesłuchania G. Müllera, 18 IX 1939, k. 141.

22 „Wollt ihr euch miterschießen lassen?”. Słowo „erschießen” rozumieć można też w znaczeniu „rozstrzelać”, BAMA Freiburg, RW 2-48, Protokół przesłuchania G. Kiwusa, 19 IX 1939, k. 144. Jak podaje portal Volksbund Deutsche Kriegsgräberfürsorge e.V., kapelmistrz Heinrich Cop urodził się 7 maja 1911 r. w Zabrzu.

${ }^{23}$ BAMA Freiburg, RW 2-48, Protokół przesłuchania H. Schloerba, 18 IX 1939, k. 135.

${ }^{24}$ Uczynić miał tak np. feldfebel Müller, co opisywał później następująco: „Ich hörte dann, daß Gewehre durchgeladem wurden. Als ich mich etwas umdrehte, sah ich, daß die Polen mit dem Gewehr in Anschlag standen. Im selben Augenblick setzte auch schon heftiges Gewehr- und Maschinengewehrfeuer ein. Da floh ich rechts an der Scheune vorbei”, BAMA Freiburg, RW 2-48, Protokół przesłuchania G. Müllera, 18 IX 1939, k. 141. Lemser podawał natomiast: „Da lief ich mit noch einigen anderen Kameraden im Schutze der Dämmerung davon", ibidem, Protokół przesłuchania K. Lemsera, 17 IX 1939, k. 132. Po usłyszeniu strzałów zbiec miał również Kiwus, ibidem, Protokół przesłuchania G. Kiwusa, 19 IX 1939, k. 144. 
że przynajmniej kilku uczyniło to jeszcze na moment przed otwarciem ognia, uznając powyższe przygotowania za wystarczający powód do podjęcia próby ratowania życia ${ }^{25}$. Sprzymierzeńcem okazał się tu zapadający zmierzch. Ci, którym udało się zbiec, słyszeć mieli jeszcze dochodzące z oddali, stopniowo milknące krzyki i wołania o ratunek ${ }^{26}$. Inni, udający martwych słyszeli odgłosy dobijania pojedynczymi strzałami rannych, błagających o darowanie życia. Dobijano zapewne także przy pomocy bagnetów; udający martwego Schloerb otrzymać miał trzy pchnięcia w udo, służące bez wątpienia sprawdzeniu, czy jeszcze żyje ${ }^{27}$.

W dalszej części tej historii zasadniczą rolę odegrać miała wspomniana już stodoła. Najbardziej dramatycznie brzmią tu zeznania Schloerba. Jak twierdził, po ustaniu strzałów na około 15 minut zapaść miała cisza, jedynie „Polacy omawiali coś pomiędzy sobą"28.

Ostrożnie się podniosłem - kontynuował - by zorientować się, jak wygląda to wokół mnie. Zobaczyłem wówczas leżących wokoło jakichś 20 do 30 martwych kolegów. Zauważyłem następnie, że zabici wleczeni są do stodoły. Również i ja zostałem podniesiony przez dwóch mężczyzn i zaniesiony w to samo miejsce. Położono na mnie warstwę słomy, a na niej dwóch kolejnych martwych kolegów. Nie wiem, co działo się później. Kiedy odzyskałem przytomność, wszędzie wokół mnie płonęło. Płomienie zbliżały się już do mnie. Nogami zepchnąłem z siebie obydwu zabitych. Kiedy wypadli na zewnątrz, natychmiast rozległy się strzały z karabinu maszynowego. Ja sam, ścigany ogniem karabinu maszynowego pobiegłem w jakieś kartoflisko. Tam rzuciłem się na ziemię i tarzając się zdusiłem płomienie, które ogarnęły już cały mój mundur ${ }^{29}$.

${ }^{25}$ Uczynił tak np. strzelec Fischer. Później w przesłuchaniu mówił, iż nie chciał czekać, aż padnie rozkaz otwarcia ognia, BAMA Freiburg, RW 2-48, Protokół przesłuchania W. Fischera, 18 IX 1939, k. 139.

${ }^{26}$ BAMA Freiburg, RW 2-48, Protokół przesłuchania K. Lemsera, 17 IX 1939, k. 132133. Kiwus podawał natomiast, że po ucieczce i ukryciu się na kartoflisku przez około 20 minut miał jeszcze słyszeć pojedyncze strzały. Ibidem, Protokół przesłuchania G. Kiwusa, 19 IX 1939, k. 144.

27 BAMA Freiburg, RW 2-48, Protokół przesłuchania H. Schloerba, 18 IX 1939, k. 135.

28 „Die Polen besprachen etwas miteinander”, BAMA Freiburg, RW 2-48, Protokół przesłuchania H. Schloerba, 18 IX 1939, k. 135.

29 „Ich richtete mich vorsichtig auf, um zu sehen, wie es um mich herum auss[i]eht. Da sah ich wohl 20 bis 30 Kameraden tot liegen. Ich merkte dann, daß die Toten in eine Scheune geschleppt wurden. Auch ich wurde von 2 Mann hochgehoben und dorthin gebracht. Die Polen legten eine Lage Stroh auf mich und auf das Stroh 2 tote Kameraden. Was dann geschah, weiß ich nicht mehr. Als ich wieder zu Bewußtsein kam, brannte es um mich herum. Die Flammen waren schon in meiner Nähe. Ich zog die Beine an und stieß die beiden Toten ins Freie. Als sie draußen hinfielen, setzte Maschinen- 
Później zarówno Schloerb (choć ciężko poparzony), jak i inni ocaleni dotrzeć zdołali do niemieckich linii.

Przynajmniej kilku ocalałych - wśród nich również feldfebel Kiwus wkrótce ponownie trafiło do Stopnicy, tym razem już w ramach prowadzonego przez Wehrmacht postępowania wyjaśniającego okoliczności zdarzenia. Wizyta Kiwusa jest o tyle istotna, że w swoim zeznaniu zawarł on opis miejsca walk oraz egzekucji, oddając stan, jaki ukazał się jego oczom nazajutrz, czyli 10 września 1939 r. Przy autobusie zatem odnaleźć miano zwłoki podoficerów Markerta vel Merkerta i Langego, jak również strzelca Frankego. Na ciele pierwszego widoczny był postrzał w głowę oraz dwa pchnięcia bagnetem: w brzuch i w pierś. Udawszy się następnie w kierunku stodoły, w jej zgliszczach odnaleźć miano „18 do 20 zwęglonych ciał”. Wokół spalonej budowli znaleziono również dwóch martwych i dwóch ciężko rannych żołnierzy. Wśród tych pierwszych znajdował się nieznany z nazwiska kierowca autobusu, z widocznymi na twarzy śladami oparzeń (zatem i on musiał znajdować się w płonącej stodole); drugim był podoficer nazwiskiem Stengelin. Ciężko ranni, czyli podoficer Schulze oraz strzelec Fritsche, trafili w międzyczasie do szpitala ${ }^{30}$.

Cytowane dokumenty w naukowym obiegu funkcjonują już co najmniej od 1979 r., kiedy to amerykański prawnik i historyk Alfred-Maurice de Zayas przywołał je w swojej wielokrotnie wznawianej pracy o Placówce Dochodzeniowej ds. Naruszeń Prawa Międzynarodowego ${ }^{31}$.

\section{Inne czynności placówek Wehrmachtu}

Z zapisów w przytoczonych wcześniej protokołach przesłuchań wynika jednoznacznie, iż podjęte przez radcę Schölza czynności nie były $\mathrm{w}$ tej sprawie pierwszymi. Ocaleli żołnierze niemal natychmiast po

gewehrfeuer ein. Ich selbst lief durch das Maschinengewehrfeuer durch bis zu einem Kartoffelacker. Dort wälzte ich mich hin und her und erstickte die Flammen, die schon meine ganze Uniform erfaßt hatten", BAMA Freiburg, RW 2-48, Protokół przesłuchania H. Schloerba, 18 IX 1939, k. 135.

30 „In der Scheune sahen wir 18 bis 20 verkohlte Leichen liegen”, BAMA Freiburg, RW 2-48, Protokół przesłuchania G. Kiwusa, 19 IX 1939, k. 144-145.

31 A.-M. de Zayas, Die Wehrmacht-Untersuchungsstelle. Deutsche Ermittlungen über alliierte Völkerrechtsverletzungen im Zweiten Weltkrieg, Monachium 1979, s. 230-232. W 2012 r. ukazało się ósme, poszerzone wydanie tej pracy pod nieco zmienionym tytułem (Die Wehrmacht-Untersuchungsstelle für Verletzungen des Völkerrechts. Dokumentation alliierter Kriegsverbrechen im Zweiten Weltkrieg, Beltheim-Schnellbach 2012). W 1989 r. ukazało się natomiast wydanie anglojęzyczne (idem, The Wehrmacht War Crimes Bureau 1939-1945, London 1989). 
zameldowaniu się w najbliższej niemieckiej jednostce składali stosowne zeznania; później powtarzali je jeszcze, bywało, parokrotnie. Feldfebel Müller, gdy tylko natknął się na niemiecki patrol, przewieziony został do Krakowa i tam „krótko przesłuchany przez jakiegoś podporucznika”32. Sugerując się najobszerniejszymi pod tym względem zeznaniami Kiwusa zakładać można, że nie było to przesłuchanie ostatnie; sam Kiwus, jak podawał, już nazajutrz po ucieczce ze Stopnicy złożył wespół z podoficerem Hampuschem relację jakiemuś pułkownikowi. Tenże zawiózł ich do sztabu 27. DP, gdzie opowieści obydwu żołnierzy wysłuchał z kolei dowódca jednostki, gen. Friedrich Bergmann. Zawieziony następnie do Stopnicy, uczestniczył w oględzinach miejsca zdarzenia, po czym został ponownie przesłuchany, tym razem przez prowadzącego czynności kpt. Dombretta ze sztabu 15. ppanc. Po powrocie do Żagania miał być przesłuchiwany jeszcze dwukrotnie ${ }^{33}$.

W jakiś sposób oddaje to dużą intensywność samego postępowania, później zaś niewątpliwie śledztwa. Jeszcze 10 września 1939 r. wspomniany kpt. Dombrett wykonał fotograficzną dokumentację miejsca zdarzenia oraz zgliszcz stodoły wraz ze zwłokami. Do oględzin, co ciekawe, przybrano troje świadków spośród miejscowej ludności, którzy następnie podpisać mieli stosowny protokół ${ }^{34}$. W ślad za wrześniowymi czynnościami poszły też środki natury policyjnej: choć świadkowie nie byli w stanie określić jednostki, z której pochodzili zamieszani w sprawę polscy żołnierze, ani tym bardziej podać nazwisk dowódców, ustalenie tych faktów nie było trudne. Bardzo szybko zidentyfikowano również zaangażowany $\mathrm{w}$ incydent pododdział oraz, co za tym idzie, bezpośrednich wykonawców. Tych drugich, niewątpliwie posiłkując się zeznaniami polskich jeńców, wkrótce już znano z imienia i nazwiska. Odpowiedzialność, jak uznano, spoczywać miała na żołnierzach 1. batalionu 201. pp, ściślej - jego 1. kompanii ckm.

Do chwili sformowania 55. DP batalion ten nosił nazwę 55. Batalionu Obrony Narodowej (ON) „Katowice”, kompania zaś - Kompanii

32 „Wir wurden mitgenommen und nach Krakau gebracht. Hier wurde ich von einem Leutnant ganz kurz vernommen", BAMA Freiburg, RW 2-48, Protokół przesłuchania G. Müllera, 18 IX 1939, k. 141.

33 BAMA Freiburg, RW 2-48, Protokół przesłuchania G. Kiwusa, 19 IX 1939, k. 144-145.

34 BAMA Freiburg, RW 2-48, Protokół przesłuchania G. Kiwusa, 19 IX 1939, k. 145. W dzienniku bojowym 5. Dywizji Pancernej lakoniczna wzmianka o incydencie pojawiła się dopiero pod datą 12 września 1939 r., o godz. 8.00. Zapis brzmi: „Im Laufe des Tages wird bekannt, daß das Musikkorps des Pz. Rgt. 15 am 10.9. [sic!] in Stopnica bestialisch ermordet sei. Nur 3 Mann sind entkommen", BAMA Freiburg, RH 27-5/175, Dziennik bojowy 5. DPanc, 12 IX 1939, k. 16. 
ON „Mikołów”. Na ich czele 9 września 1939 r. stali - odpowiednio wspomniany już kpt. Paweł Blew oraz kpt. Tytus Wikarski ${ }^{35}$. Stosownie do nazwy, żołnierze kpt. Wikarskiego rekrutowali się na ogół spośród mieszkańców położonego w ówczesnym powiecie pszczyńskim Mikołowa.

\section{Czynności policyjne}

Nic dziwnego, że również i tam wszczęto pewne czynności. Pojęcie o tym daje notka, jaką 13 października 1939 r. zamieszczono w dzienniku mikołowskiego posterunku policji ochronnej (Schupo): „Strażnik zakładowy Max Schuster, zamieszkały w Mikołowie, Löffelstr[aße] 22 donosi, iż słyszał, że niejaki Schwiderski, zamieszkały w Mikołowie, Kanalstr[aße] 30 strzelał do [niemieckich] żołnierzy z k[arabinu] m[aszynowego]. Sch[widerski] zastrzelił wszystkich wziętych do niewoli Niemców. Schwiederski [sic!] ob[ecnie] nie przebywa w Mikołowie, jest on polskim żołnierzem" ${ }^{36}$.

Spodziewać się można, że kpr. Franciszek Świderski (bo o nim to niewątpliwie mowa) powrócił do miasta już w kilka dni po sporządzeniu tej adnotacji. Na pewno też natychmiast został aresztowany i osadzony w mikołowskim więzieniu sądowym ${ }^{37}$. I na to, i na inne jeszcze okoliczności wskazuje kolejna notka, już z 19 października 1939 r.:

Rzeźnik Max Zimmer, zamieszkały w Mikołowie, Kattowitzerstr[aße] 15, donosi, że jako polski żołnierz zaobserwował następujące zdarzenie. Pewien polski oficer - którego nazwisko jest nieznane - zarządził rozstrzelanie 43 niemieckich żołnierzy, wziętych wcześniej do niewoli. Zamieszkały w Mikołowie, Kanalstr[aße] 18 Bernhard Kmietzik miał podjąć się rozstrzelania

${ }^{35}$ J. Przemsza-Zieliński, Księga wrześniowej chwały pułków śląskich, t. 2, KatowiceSosnowiec 1993, s. 157.

36 „Der Werkschutzmann Max Schuster, Nikolai, Löffelstr. 22 wohnhaft, zeigt an, dass er gehört habe, dass ein gewisser Schwiderski Nikolai, Kanalstr. 30 wohnhaft Soldaten mit einem MG [Maschinengewehr] abgeschossen hätte. Sch. hat sämtliche deutschen Gefangenen erschossen. Schwiederski ist z. Zt. [zur Zeit] noch nicht in Nikolai, er ist polnischer Soldat", AP w Katowicach (dalej: Ka), Rejencja Katowicka (dalej: RK), 4252, Dziennik mikołowskiej policji ochronnej, 13 X 1939, k. 202.

${ }^{37} \mathrm{Na}$ taki scenariusz wskazywała w powojennym przesłuchaniu żona Świderskiego: „W roku 1939, gdy mąż mój powrócił z wojska polskiego, a było to jakoś w m[iesią] cu październiku, do domu przyszedł rano, a w południe został aresztowany przez gestapo i osadzony w areszcie policyjnym w Mikołowie, gdzie po dwóch dniach zginął", AIPN w Katowicach (dalej: Ka), Sąd Okręgowy w Katowicach 1945-1950 (dalej: SO Ka 1945-1950), IPN Ka 564/348, Protokół przesłuchania świadka Teresy Paduch primo voto Świderskiej, 3 VIII 1946, k. 8v. 
niemieckich jeńców za pomocą $\mathrm{k}$ [arabinu] m[aszynowego]. Innymi sprawcami byli kupiec Franz Swiderski, zamieszkały w Mikołowie, Plebis[zit] str[aße] 18, oraz robotnik Stanislaus Pajonk, zamieszkały w Mikołowie, Kanalstr[aße] 25. Sprawcy twierdzą, że zadanie takie otrzymali od polskiego majora [nazwiskiem] Pleff. Major ten znajduje się w obozie jenieckim w Niemczech. Swiderski nie mógł zostać przesłuchany w trakcie dalszych czynności, ponieważ w dniu 18 października 1939 r. około godziny 11.00 powiesił się w celi aresztanckiej więzienia policyjnego. Podejrzani Kmiecik, [Stanisław] Stakowiak [sic!] i Pajonk doprowadzeni zostali do obozu jeńców wojennych w Sośnicy pod Gliwicami ${ }^{38}$.

Oczywiście, przedstawionym dokumentom zarzucić można ich „niemiecką" proweniencję, by następnie, jak w podobnej sytuacji czyni to choćby sam Przemsza-Zieliński, dywagować nad stosowanymi przez okupanta mechanizmami dyskredytowania żołnierzy Września. Autor znajduje się jednak w sytuacji o tyle komfortowej, iż miast przytaczania kolejnych argumentów na rzecz poważnego potraktowania protokołów radcy Schölza oraz zapisów w policyjnym dzienniku, przywołać może zarówno relację zaangażowanego bezpośrednio w te wydarzenia polskiego oficera, jak i powojenne świadectwa, sporządzone przez funkcjonariuszy ówczesnego państwa polskiego. Kwestionowanie ich autentyczności może być już nie tyle trudne, co wręcz niemożliwe.

38 „Der Fleischer Max Zimmer in Nikolai, Kattowitzerstr. 15 wohnhaft, zeigt an, dass er als polnischer Soldat folgende Wahrnehmung gemacht habe. Ein polnischer offizier - dessen Name unbekannt ist - ordnete die Erschiessung von 43 deutschen Soldaten an, die zuvor gefangen genommen waren. Bernhard Kmietzik Nikolai, Kanalstr. 18 wohnhaft, haben die Erschiessung der deutschen Gefangenen, mittels eines MG, vorgenommen. Es waren hierbei noch die Täter Kaufmann Franz Swiderski, Nikolai, Plebisstr. 18 und der Arbeiter Stanislaus Pajonk Nikolai, Kanalstr. 25 wohnhaft. Die Täter behaupten, von dem polnischen Major Pleff dazu beauftragt worden sein. Dieser Major befindet sich in einem Kriegsgefangenlager in Deutschland. Swiederski [sic!] konnte zu den weiteren Ermittlungen nicht mehr gehört werden, da er sich in der Arrestzelle des Polizeigefängnisses am 18. Oktober 1939, gegen 11.00 erhängt hatte. Die Beschuldigten Kmiecik [sic!], Stakowiak und Pajonk sind dem Kriegsgefangenlager in Oehringen bei Gleiwitz zugeführt", AP Ka, RK, 4252, Dziennik mikołowskiej policji ochronnej, 19 X 1939, k. 196. Major Pleff jest niewątpliwie tożsamy z kpt. Pawłem Blewem. Gdy chodzi o przyczyny śmierci F. Świderskiego, wersję samobójstwa podaje również zapis w akcie zgonu. Archiwum USC w Mikołowie, Księga zgonów II za rok 1939, Akt zgonu nr 30/39, 18 X 1939. Tymczasem w Mikołowie śmierć Świderskiego do dziś przedstawiana jest jako mniej lub bardziej zakamuflowana egzekucja: „Kapral Franciszek Świderski [- - ] był aresztowany i przesłuchiwany w siedzibie Gestapo w Mikołowie. Zamordowany został 18 października 1939 r.; ciała nie wydano rodzinie. Pochowano go anonimowo na cmentarzu przy kościele św. Wojciecha w Mikołowie”, R. Szendzielarz, B. Bromboszcz, Mikołów z perspektywy 150 lat, Mikołów 2009, s. 416. 
Relacja por. Zbigniewa Józefa Jabłońskiego

Jabłoński, oficer rezerwy, w trakcie mobilizacji przydzielony został do 201. pp w charakterze drugiego adiutanta ${ }^{39}$. W lutym $1940 \mathrm{r}$. znalazł się we Francji, gdzie - jak wszyscy uczestniczący w kampanii 1939 r. oficerowie - pojawić się musiał w Biurze Rejestracyjnym płk. Fryderyka Mally'ego, by złożyć zeznania na temat swego udziału w walkach. Oto, co miał on do powiedzenia w odniesieniu do Stopnicy:

Podczas biwaku naszego i innych pułków, wchodzących w skład 55. Dywizji, mimo przygotowanej na wylotach wszystkich szos wychodzących ze Stopnicy obrony, głównie przeciwczołgowej, niespodzianie wjeżdża do środka miasta autobus w kolorze ceglastoczerwonym z około 30 żołnierzami niemieckimi. Znajduję się w tej chwili na ulicy w drodze po rozkazy do D[owód]cy Piechoty Dywizyjnej i w pobliżu apteki „Pod Filarami” widzę, jak autobus zostaje przez naszych żołnierzy ostrzelany z karabinów. Niemcy odpowiadają na to również ogniem karabinowym, lecz po krótkiej strzelaninie widząc się otoczonymi ze wszystkich stron - poddają się. Okazuje się, że jestem jedynym oficerem w tej chwili na miejscu. Obejmuję więc komendę i rozkazuję zebrać wszystkich jeńców na podwórzu przy aptece oraz przeszukać kieszenie ich za bronią i dokumentami. Jeńców niemieckich skierowuję do pobliskiego Komisariatu Policji. Wybrawszy dwóch najstarszych podoficerów spośród nich, odprowadzam ich pod eskortą dwóch żołnierzy z bagnetami na broni - do D[owódz]twa Dywizji. Niemcy po drodze tłumaczą się, że są członkami orkiestry niemieckiego pułku czołgów, który poprzedniego dnia był w Stopnicy. Jednak żadnych instrumentów muzycznych, ani w autobusie, ani przy żołnierzach - nie znaleziono. [--] Owych dwóch jeńców niemieckich doprowadziłem natychmiast do płk. Kalabińskiego, dowódcy 55. Dywizji. Oświadczył on, że nie można bawić się z jeńcami niemieckimi i że trzeba ich rozstrzelać. Uważając, że w każdym razie przed ewent[ualną] egzekucją należy przesłuchać jeńców, aby dowiedzieć się szczegółów o pobliskim oddziale czołgów niemieckich, ofiarowałem się być tłumaczem, po[nie]waż w tej chwili nie było na miejscu oficera znającego język niemiecki. Jednak płk Kalabiński kazał mi wrócić do oddziału. Podobno wszyscy jeńcy niemieccy schwytani w tym dniu w Stopnicy, wraz z dywersantami znalezionymi w ubraniach cywilnych po domach prywatnych, zostali wieczorem rozstrzelani. Był to fakt o tyle w skutkach swych brzemienny, że - jak słyszałem później w szpitalu od naszych oficerów i żołnierzy w niewoli niemieckiej - Niemcy odtąd też rozstrzeliwali jeńców polskich, twierdząc, że to jest odwet za Stopnicęe $e^{40}$.

${ }^{39}$ We wspomnieniach W. Adamczyka błędnie podano, iż miał on na imię Stanisław. Zob. W. Adamczyk, op. cit., s. 317 i 323; również s. 14.

${ }^{40}$ IPMS, B.I.57.B, Relacja por. Z.J. Jabłońskiego, 7 II 1940, b.pag. Ostatnie zdanie pośrednio potwierdza W. Steblik, pisząc o wymordowaniu przez Niemców 12 września 
Trudno tu, na dobrą sprawę, cokolwiek dodać. To właśnie por. Jabłoński musiał być owym oficerem ,z trzema gwiazdkami na kołnierzu” (abstrahując tu od błędnego oznaczenia stopnia), zapamiętanym przez niemieckich jeńców; zgadza się również informacja o dwóch najstarszych podoficerach, odesłanych do sztabu dywizji. Zauważmy przy tym, że relacja ta powstała $\mathrm{w}$ zaledwie pięć miesięcy po całym incydencie, do tego w okolicznościach niesprzyjających raczej fantazjowaniu.

\section{Sprawy Pawła Kłoska i Wincentego Świerkota}

Mowa tym razem o dwóch sprawach karnych, jakie tuż po wojnie prowadzone były przeciwko byłym żołnierzom kompanii ON „Mikołów”, podejrzanym o denuncjowanie niemieckim władzom swoich towarzyszy broni, biorących czynny udział w incydencie ${ }^{41}$. Pierwsza z nich dotyczyła zamieszkującego wówczas w podrybnickich Folwarkach Pawła Kłoska. W sierpniu 1946 r. przesłuchano go w charakterze podejrzanego; z uwagi na wage jego zeznań, przytoczyć należy je w całości:

Gdy w 1939 r. we wrześniu powróciłem z wojny, w której brałem udział jako członek Mikołowskiej Komp[anii] Obrony Narodowej, zostałem zabrany przez Gestapo i przewieziony do willi, którą przed wojną zamieszkiwał dr [Emanuel] Hałacz. Tam przesłuchiwali mnie około dwie godziny i wypuścili. Na drugi dzień przyjechali po mnie znowu i ponownie przesłuchiwali dwie godziny, po czym wypuścili mnie do domu. Po kilku dniach zabrali mnie jeszcze raz i trzymali dzień i noc. W czasie przesłuchiwań pytali się mnie, jak się to stało, że grupa jeńców niemieckich w Stopnicy koło Krakowa została przez Obronę Narodową rozstrzelana. Ja zeznałem im, że w[e] wspomnianej miejscowości stała wtedy Mikoł[owska] Komp[ania] Obrony Narod[owej] i w czasie naszego postoju przyjechał autobus z żołnierzami niemieckimi. Żołnierze ci zostali rozbrojeni i wzięci do niewoli. Pluton kapr[ala] [Franciszka] Świderskiego, w którym się wtedy znajdowałem, został odkomenderowany do odprowadzenia tych jeńców na tyły linii frontu. Po odprowadzeniu ich około czterech k[ilo]m[etrów] od Stopnicy konwój z jeńcami zatrzymał się w polu. W pobliżu znajdowało się tylko jedno obejście gospodarskie (dom i stodoła). Tam kapr[al] Świderski kazał jeńców otoczyć, żeby nie zbiegli. W pewnym momencie jeden z jeńców zaczął uciekać i kapr[al] Świderski dał rozkaz strzelać. Wtedy wszyscy zaczęli strzelać do jeńców,

1939 r. w Szczucinie „około 70 polskich żołnierzy - jeńców i osób cywilnych”, W Steblik, op. cit., s. 424 .

${ }^{41}$ AIPN Ka, SO Ka 1945-1950, IPN Ka 564/348. 
w wyniku czego siedemnastu z nich zostało zastrzelonych, a reszta zbiegła. Ja nie strzelałem, bo miałem karabin bez naboi. [Stanisław] Pająk strzelał z ręcznego karabinu maszyn[owego], [Paweł] Mendrok zaś i pozostali z karabinów [ręcznych]. Następnie wróciliśmy z powrotem do Stopnicy, skąd d[owód]ca batalionu [kapitan Paweł Blew] wysłał kapr[ala] Świderskiego z kilku ludźmi na miejsce poprzedniego wypadku celem zatarcia śladów, które to zadanie Świderski wykonał znosząc trupy do stodoły i podpalając ją. Świderski dołączył do kompanii dopiero dwa dni później. Kiedy się mnie pytali, czy [Bernard] Kmiecik też strzelał, powiedziałem, że nie widziałem, ale że Kmiecik później pokazywał zegarek, który miał mieć od jeńca niemieckiego. Powiedziałem jeszcze na Gestapo, że byłem obecny, gdy Świderski kazał strzelać [do] rannych Niemców, mimo że prosili, by ich nie strzelać, bo mają żony i dzieci. Takie były moje całe zeznania przed Gestapo i więcej $\mathrm{w}$ tej sprawie nie mam nic do powiedzenia ${ }^{42}$.

Mimo to w trzy miesiące później został Kłosek ponownie przesłuchany. Tym razem powiedział tylko:

Do Mikołowa wróciłem około 15 września 1939 r., dokładnego dnia sobie nie przypominam, a w dwa tygodnie po moim powrocie zostałem wezwany do Gestapo w Mikołowie. Skąd się policja niemiecka dowiedziała o rozstrzeliwaniu jeńców niem[ieckich] przez kompanię Obrony Narodowej, tego nie wiem. W toku przesłuchania mnie policja niemiecka wymieniała nazwiska [Franciszka] Świderskiego, [Bernarda] Kmiecika, [Stanisława] Pająka, [Pawła] Mędroka. Skąd i w jaki sposób o tych nazwiskach policja niemiecka dowiedziała się, tego nie wiem. Ja tych nazwisk nie ujawniłem niemieckiej policji. Po przesłuchaniu w jakiś czas zostałem przez Gestapo zwolniony. Do oddziału Obrony Narodowej należałem, jednak do niemców [sic!] jeńców wojennych wówczas w Stopnicy nie strzelałem ${ }^{43}$.

${ }^{42}$ AIPN Ka, SO Ka 1945-1950, IPN Ka 564/348, Protokół przesłuchania podejrzanego P. Kłoska, 14 VIII 1946, k. 16-16v. W willi dr. Hałacza, położonej vis à vis wspomnianego więzienia, mieściła się placówka niemieckiej policji ochronnej; najbliższa placówka Gestapo znajdowała się wówczas w Katowicach. Oczywiście, przynajmniej niektóre przesłuchania podejrzanych o tak poważny delikt prowadzić mogli przybyli z zewnątrz funkcjonariusze Gestapo; w mieście nie posiadali oni jednak swojej stałej siedziby, G. Bębnik, Mikołów w początkach II wojny światowej, Mikołów 2009, s. 56-57. Stawianie na czele plutonu zaledwie kaprala dowodzi olbrzymich kłopotów kadrowych, z jakimi borykały się dywizje rezerwowe. Podpułkownik Adamczyk pisał m.in.: „Podoficerowie rezerwy - jakby w obawie przed zbyt trudnymi obowiązkami i przed odpowiedzialnością nie przyznają się do swych stopni”, W. Adamczyk, op. cit., s. 25. W miarę upływu czasu i związanych z tym strat osobowych problem braku kadry mógł się tylko pogłębiać.

${ }^{43}$ AIPN Ka, SO Ka 1945-1950, IPN Ka 564/348, Protokół przesłuchania podejrzanego P. Kłoska, 20 XI 1946, k. 18. 
Zwróćmy tu uwagę na kilka istotnych momentów. Po pierwsze, dopiero pod sam koniec pierwszego przesłuchania pojawiają się pewne znaczące szczegóły (dobijanie rannych, zabrany jednemu z jeńców zegarek), które to znalazły się w zeznaniach składanych wcześniej przed niemiecką policją. Kłosek jednak nie dystansuje się od swych wcześniejszych wyjaśnień, jednoznacznie obciążających kpr. Świderskiego i przynajmniej kilku innych żołnierzy kompanii „Mikołów”; nie usiłuje też zasłaniać się naciskami ze strony niemieckich policjantów. Ba, owe zeznania wyraźnie afirmuje! Po drugie, zilustrowany przezeń przebieg wydarzeń wydaje się być mocnym argumentem na rzecz tezy o egzekucji, i to pomimo wzmianki o otwarciu ognia dopiero z chwilą podjęcia przez jednego z Niemców próby ucieczki; dobijanie rannych nie mieści się wszak w zwyczajowym sposobie postępowania $\mathrm{z}$ uciekającymi jeńcami. Po trzecie, zastanawiająca jest podawana przez Kłoska liczba zabitych; jest to jedynie 17 jeńców, przy czym reszta miałaby zbiec (choć trudno przypuszczać, by usiłował wówczas Kłosek liczyć leżące na polu ciała; może po prostu usłyszał o tym później od jednego z uczestniczących w „uprzątaniu”?). Po czwarte wreszcie, z pierwszego zeznania wynika, iż pomiędzy strzelaniną a zniesieniem ciał do stodoły i jej podpaleniem upłynąć miało więcej czasu, niż podawali to ocaleni Niemcy; mowa jest wręcz o ponownym udaniu się w to samo miejsce, celem już literalnie „zatarcia śladów”. Skąd zatem wzięłyby się wymieniane w niemieckich zeznaniach zwłoki, leżące nie w stodole, a obok niej, w polu? Czyżby Świderski do zleconego mu zadania podszedł w aż tak niefrasobliwy sposób? Czy też może w ciemnościach nocy po prostu nie zauważył wszystkich zabitych, ewentualnie ciężko rannych?

Niewątpliwie mikołowscy funkcjonariusze Schupo starali się przesłuchać możliwie wielu powracających do domów żołnierzy kompanii „Mikołów”. Jeden z nich, Józef Ulrich, zeznał po wojnie:

Do domu powróciłem 15 września tego roku, po tygodniu czasu dostałem wezwanie na Gestapo, gdzie zapytano mnie na podstawie protokołu zeznania Kłoska, czy jest mi wiadomo, że Franke i Mędrak [sic!] urzynali uszy i wybijali oczy jeńcom niemieckim. Ja odpowiedziałem, że jest to nieprawda, przypominam sobie jeszcze, że jak zeznał Kłosek na Gestapo, to prawdopodobnie miał powstrzymywać Mędraka od strzelania [do] niemców [sic!]. [--] Nadmieniam, że Kłosek wyraźnie zeznał, że Mędrak strzelał do niemców [sic! ] ${ }^{44}$.

Zauważmy wreszcie, że sam fakt strzelania do jeńców (czy wręcz ich rozstrzelania) nie jest przez nikogo kwestionowany; ani przez

${ }^{44}$ AIPN Ka, SO Ka 1945-1950, IPN Ka 564/348, Protokół przesłuchania świadka J. Ulricha, 3 VIII 1946, k. 11v. 
oskarżonego, ani przez prokuratora, ani wreszcie przez sąd. Prowadzący sprawę Kłoska prokurator katowickiego Specjalnego Sądu Karnego Aleksander Nowak, wnioskując o powtórne przesłuchanie podejrzanego, otwarcie pisał, iż interesują go informacje „skąd policja niemiecka dowiedziała się o rozstrzeliwaniu jeńców niemieckich przez kompanię Obrony Narodowej, [--] kiedy policja niemiecka zwolniła podejrzanego, mimo należności jego do oddziału Obrony Narodowej, który wykonał egzekucję" ${ }^{45}$. Podobnie szczery był, wnioskując o umorzenie postępowania: „Podejrzanemu zarzuca się, że w[e] wrześniu 1939 r. ujawnił przed tajną policją niemiecką, iż [Stanisław] Pająk, [Paweł] Mędrok, [Jan] Franke i inni jako członkowie kompanii Obrony Narodowej w czasie działań wojennych w[e] wrześniu 1939 r. wystrzelali w Stopnicy oddział jeńców niemieckich przez nich konwojowanych" ${ }^{46}$. Jak widać, zainteresowanie tego przedstawiciela wymiaru sprawiedliwości wzbudzały wyłącznie personalia osób, które ujawniły domniemanych sprawców.

Obszerniejsze są akta sprawy kolejnego żołnierza kompanii „Mikołów", Wincentego Świerkota, choć w jego przypadku próżno doszukiwać się podobnie jednoznacznych zeznań. Nie są one jednak pozbawione wartości; np. świadek Klemens Świderski (młodszy brat F. Świderskiego), relacjonował zarówno pojawienie się brata w Mikołowie („[Franciszek Świderski] zrzucał w tej chwili mundur Obrony Narod[owej] i przygotowywał się do ucieczki”), docierające do miasta wieści o „incydencie” („Po swoim powrocie z ucieczki były pogłoski w Mikołowie, iż kompania Obrony Narodowej brała udział w rozstrzeliwaniu Niemców i jako takich poszukują [jej żołnierzy] władze okupacyjne"), jak i aresztowanie St. Stachowiaka przez funkcjonariusza Schupo (, policjant niemiecki przystąpił do Stachowiaka obecnego tam i odwiózł go motocyklem na policję. Słyszał też słowa jakiegoś osobnika, który wołał «to jest ten, on dwóch Niemców rozstrzelał», była też mowa o jakimś zegarku oraz o tym, iż wykłuwał on [Stachowiak - G.B.] oczy bagnetem") ${ }^{47}$. Swoje znaczenie ma również

45 AIPN Ka, SO Ka 1945-1950, IPN Ka 564/348, Pismo prokuratora SSK do Sądu Grodzkiego w Mikołowie, 3 X 1946, k. 20.

${ }^{46}$ AIPN Ka, SO Ka 1945-1950, IPN Ka 564/348, Wniosek o umorzenie dochodzenia, 13 XII 1946, k. 26v.

47 AIPN Ka, SO Ka 1945-1950, IPN Ka 564/348, Protokół rozprawy głównej, 19 VI 1947, k. 44v-45. We wcześniejszym protokole przesłuchania K. Świderski wskazywał na W. Świerkota, zeznając: „Wtem nadchodzi Świerkot wraz z policjantami niem[ieckimi] i słyszałem, jak powiedział na Stachowiaka: «To jest pieroński Polak, który pomordował dużo niemców [sic!] i jednemu zabrał zegarek», wtedy policja doszła do Stachowiaka, zabrali go na motocykl”, ibidem, Protokół przesłuchania świadka K. Świderskiego, 4 VIII 1946, k. 15v. 
zeznanie świadka Jana Nowaka (m.in. dzięki niemu Świerkot został uniewinniony), brzmiące: „Przypomina sobie dokładnie, iż na początku okupacji w niepamiętnym zeznającemu dniu byli na rynku z oskarżonym, lecz po paru zamienionych słowach przystąpił do oskarżonego policjant i zabrał go ze sobą. Po $15 \mathrm{~min}$ [utach] oskarżony powrócił i na pytanie świadka odpowiedział, iż tam nie potrzebują takich, co nic nie widzieli" ${ }^{48}$. Wreszcie i sam Świerkot, już jako oskarżony, podawał w trakcie rozprawy, że „zostali wyparci do Kazimierza Wielkiego [chodzi o Kazimierzę Wielką - G.B.] i tam schwytano około 40 jeńców niem[ieckich], kto do tych jeńców strzelał, nie wie”, oraz że „na drugi dzień po powrocie $\mathrm{z}$ niewoli rozmawiał z Leonem Manderą [--] pytał go, czy to prawda jest, że Mikołowska Komp[ania] O[brony] N[arodowej] zastrzeliła 40 jeńców niem[ieckich], na co on mu odpowiedział, że nic o tym nie wie"49.

Na szczególną uwagę zasługuje za to inna, nieobecna w sprawie Kłoska okoliczność. Otóż postępowanie przeciwko Świerkotowi nie zakończyło się umorzeniem; wobec wagi materiału dowodowego wniesiony został akt oskarżenia, po czym odbyła się rozprawa. Tu jednak oskarżyciel (był nim ponownie A. Nowak), zmuszony wymogami procedury do sformułowania zarzutów, zawahał się chyba przed otwartością, na którą pozwolił sobie w sprawie Kłoska. W postanowieniu o tymczasowym aresztowaniu Świerkota mowa jest bowiem, jakoby ten „w październiku 1939 r. działał na szkodę Stanisława Stachowiaka przez to, że wskazał go policji niemieckiej w Mikołowie jako sprawcę rozstrzelania dwóch szpiegów niemieckich [wyróżnienie - G.B.]" ${ }^{50}$. Taką kwalifikację utrzymano też zarówno w akcie oskarżenia, jak i w wyroku uniewinniającym; obydwa dokumenty w sposób jednobrzmiący podawały, jakoby Świerkot „idąc na rękę władzy okupacyjnej niemieckiej w Mikołowie w październiku 1939 r. działał na szkodę Stanisława Stachowiaka przez to, że ujawnił przed policją niemiecką, iż Stachowiak jako członek Obrony Narodowej w czasie działań wojennych we wrześniu 1939 r. zastrzelił dwu szpiegów niemieckich, skutkiem czego Stachowiak został aresztowany i wywieziony do obozu koncentracyjnego, gdzie zmarł" 51 . Tymczasem jedynym

48 AIPN Ka, SO Ka 1945-1950, IPN Ka 564/348, Protokół rozprawy głównej, 19 VI 1947, k. 46. Szeroko zakrojone przez Niemców przesłuchania dowodzą, że starano się dotrzeć do autentycznych świadków (oraz sprawców), nie zaś spreparować określony już z góry „materiał dowodowy”.

${ }^{49}$ AIPN Ka, SO Ka 1945-1950, IPN Ka 564/348, Protokół rozprawy głównej, 27 VIII 1947, k. 86-86v.

50 AIPN Ka, SO Ka 1945-1950, IPN Ka 564/348, Postanowienie o tymczasowym aresztowaniu, 13 XI 1946, k. 25.

${ }^{51}$ AIPN Ka, SO Ka 1945-1950, IPN Ka 564/348, Akt oskarżenia przeciwko W. Świerkotowi, 14 I 1947, k. 28; ibidem, Wyrok w sprawie III.K.145/47, 27 VIII 1947, k. 94. 
miejscem, w którym w ogóle pojawia się owych rzekomych „dwu szpiegów niemieckich" jest protokół przesłuchania ciotki Stachowiaka, Franciszki Adamczak, twierdzącej m.in.: „W tym samym dniu widziałam się z siostrzeńcem, który mi powiedział, że zabił dwóch szpiegów niemieckich, a Świerkot to powtórzył na policji" ${ }^{52}$. W materiałach śledztwa, poza wspomnianymi dokumentami, wątek ten nie jest w ogóle eksploatowany.

\section{Ilu właściwie?}

Na podstawie zarówno powyższych zeznań, jak i internetowej bazy Volksbund Deutsche Kriegsgräberfürsorge spróbujmy zestawić listę ofiar stopnickiego incydentu. Feldfebel Müller podawał, że po ucieczce i przewiezieniu do Krakowa natknąć miał się tam na dziewięciu kolegów, ocalałych z liczącej 46 osób grupy jeńców. Poinformować miano go także, że uratować zdołało się jeszcze trzech innych; wszyscy pozostali mieli zginąćs ${ }^{3}$. Jeśli uznamy te informacje za wiarygodne, otrzymamy 13 ocalonych oraz - siłą rzeczy - 33 zabitych.

Niestety, zweryfikowanie tych danych nie wydaje się, przynajmniej w tej chwili, możliwe. W portalu Volksbundu nie można wyświetlić poległych pod konkretną miejscowością. Z kolei dostęp do jedynego niemieckiego archiwum, mogącego służyć w takich wypadkach pomocą (mowa o tzw. Deutsche Dienststelle w Berlinie) pozostaje utrudniony z rozmaitych powodów: procedur, czasu oczekiwania, wreszcie kosztów. Jak zobaczyć można w poniższym zestawieniu, na podstawie danych z Volksbundu udało się ustalić zaledwie jedenaście niewątpliwych lub $\mathrm{z}$ dużą dozą prawdopodobieństwa - domniemanych ofiar stopnickiego incydentu. Jeśli za wiarygodne uznamy informacje feldfebla Müllera, wielkość ta stanowić będzie zaledwie jedną trzecią faktycznej liczby ofiar. Jednocześnie przynajmniej zbliżać będzie się do wielkości podanej przez jedynego znanego nam dotychczas polskiego świadka, czyli Pawła Kłoska (17 zabitych). Uderzające, że za pośrednictwem portalu nie udało się ustalić zabitego o nazwisku Markert lub też Merkert ${ }^{54}$. Wszystkie te zagadnienia wymagają na pewno dalszych, odpowiednio pogłębionych badań.

${ }^{52}$ AIPN Ka, SO Ka 1945-1950, IPN Ka 564/348, Protokół przesłuchania świadka F. Adamczak, 3 VIII 1946, k. 12v.

53 BAMA Freiburg, RW 2-48, Protokół przesłuchania G. Müllera, 18 IX 1939, k. 141-142.

${ }^{54}$ Również we wszelkich chyba możliwych fonetycznych wersjach tego nazwiska: Marquart, Marquard, Marquardt, Merquart itp. 
Tabela 1. Zestawienie uchwytnych w dokumentach żołnierzy Wehrmachtu, ofiar „incydentu” w Stopnicy

\begin{tabular}{|c|c|c|}
\hline Stopień & $\begin{array}{c}\text { Nazwisko, ew. imię i funkcja } \\
\text { (przydział) }\end{array}$ & Czy przeżył? \\
\hline \multicolumn{3}{|c|}{ Orkiestra 15. ppanc } \\
\hline \multirow[t]{3}{*}{ feldfebel } & Cop Heinrich (kapelmistrz) & nie (VB) \\
\hline & Kiwus Gerhard & tak \\
\hline & Rössner vel Rößner vel Rösner & tak \\
\hline mł. feldfebel & Kaup & nie (?) \\
\hline \multirow[t]{12}{*}{ podoficer } & Bardoskiwics vel Bardoskiwicz & tak \\
\hline & Dietz Otto & nie (VB) \\
\hline & Gebauer Richard & nie (VB) \\
\hline & Hambusch vel Hampusch & tak \\
\hline & Kröhl Herbert & nie (VB) \\
\hline & Küster & nie (?) \\
\hline & Lange Albrecht & nie (VB) \\
\hline & Lemser Kurt & tak \\
\hline & Markert vel Merkert & nie \\
\hline & Schloerb Helmut & tak \\
\hline & Schulze Gerhard lub Wilhelm & $\begin{array}{l}\text { tak (ciężko ranny, zm. } 11 \text { IX '39 w Kielcach } \\
\text { lub } 15 \text { IX '39 w Piotrkowie) (VB) }\end{array}$ \\
\hline & Stengelin, Karl Albert & nie (VB) \\
\hline \multirow[t]{4}{*}{ st. gefrajter } & Böhme, Wilhelm & nie (VB) \\
\hline & Hermannsdörfer, Helmut & nie (VB) \\
\hline & Polster & tak \\
\hline & Rauschert & nie (?) \\
\hline \multirow[t]{2}{*}{ gefrajter } & Gawron & tak \\
\hline & Pätzold & tak \\
\hline \multirow[t]{2}{*}{ strzelec } & Franke, Alfred & nie (VB) \\
\hline & Fritsche, Hermann & $\begin{array}{l}\text { tak (ciężko ranny, zm. } 11 \text { IX '39 w Osieku) } \\
\text { (VB) }\end{array}$ \\
\hline \multicolumn{3}{|c|}{ 2. DPanc } \\
\hline feldfebel & Müller, Gerhard (3. ppanc) & tak \\
\hline \multirow[t]{2}{*}{ strzelec } & Fischer, Willi (2. pstrz) & tak \\
\hline & Schneeberger (2. pstrz) & nie (?) \\
\hline
\end{tabular}

Źródło: BAMA Freiburg, RW 2-48, k. 131-145; Volksbund Deutsche Kriegsgräberfürsorge (www. volksbund.de). Uwaga: Kursywa w kolumnach nr 2 i 3 oznacza, że brak jest pewności, czy zaczerpnięte z zasobu Volksbundu (symbol VB) informacje dotyczą właśnie osób o wymienionych nazwiskach. 
Kwestia odpowiedzialności

Sposób postępowania z jeńcami wojennymi regulowała $\mathrm{w}$ tym czasie konwencja genewska z 27 lipca 1929 r., będąca rozwinięciem czwartej konwencji haskiej z 1907 r., w której to także wymieniono warunki, jakie spełniać musi strona konfliktu pragnąca korzystać z pełni „ustaw, praw i obowiązków wojennych". Na pierwszym miejscu wyszczególniono tam „posiadanie na czele osoby odpowiedzialnej za swoich podwładnych”55.

Kto zatem ponosiłby odpowiedzialność za strzelających do jeńców żołnierzy kompanii „Mikołów”? Oczywiście, na najniższym poziomie byłby to dowódca plutonu, kpr. Świderski. Jak już wiadomo, niemal natychmiast po powrocie do Mikołowa został on aresztowany i osadzony w więzieniu; tylko za sprawą samobójstwa (czy, jak chcą inni, linczu) uniknął postawienia przed sądem i najpewniej wyroku skazującego. Kolejnym szczeblem był dowódca kompanii, czyli kpt. Wikarski. Tu pierwsze zaskoczenie - Wikarski, jak większość oficerów GO „Śląsk”, dostał się do niewoli, w której to spędził całą wojnę. Osadzony został w Oflagu II C Woldenberg (obecnie Dobiegniew), był zatem najdosłowniej ,pod ręką” wszelkich niemieckich służb policyjnych. Tymczasem po wojnie powrócił do kraju; osiadłszy w Bytomiu, zmarł 8 listopada 1964 r. $^{56}$ Dowódca batalionu, wielokrotnie przewijający się w cytowanych dokumentach kpt. Blew, uniknął śledztwa oraz bardzo w jego przypadku prawdopodobnego sądu, bowiem zginął w dwa dni po opisywanych wydarzeniach, 11 września 1939 r. pod Osiekiem ${ }^{57}$. W oflagach: II B Arnswalde (Choszczno), II D Groß-Born (Kłomino), a na końcu w Oflagu VI B Dössel resztę wojny spędził też dowodzący 201. pp ppłk Adamczyk. Do kraju powrócił w 1946 r.; osiedliwszy się w Bielsku-Białej, zmarł we wrześniu 1978 r. I wreszcie sam dowódca 55. DP, czyli płk Stanisław Kalabiński. Tu zatrzymać trzeba się na dłużej.

Kalabiński nie trafił natychmiast do niewoli; na czele grupki żołnierzy zdołał przebić się z okrążenia, po czym 23 września w gajówce Nowiny rozwiązał pozostały jeszcze pod jego komendą oddziałek. Sam udał się do Warszawy, do żony. Jak podaje Przemsza-Zieliński, pułkownik zatrzymany został dopiero 7 października 1939 r. i osadzony w Oflagu IX C Rotenburg

${ }^{55}$ Dziennik Ustaw 1927, nr 21, poz. 161, Konwencja dotycząca praw i zwyczajów wojny lądowej, aneks: Regulamin dotyczący praw i zwyczajów wojny lądowej, s. 205.

56 System Rejestrów Państwowych, nr aktu 2478011/00/AZ/1964/782864, Odpis zupełny aktu zgonu T. Wikarskiego. Również: „Trybuna Robotnicza” 11 XI 1964 (dwa nekrologi T. Wikarskiego, obydwa z błędną datą zgonu 7 listopada).

${ }^{57}$ J. Przemsza-Zieliński, Księga wrześniowej chwały, s. 157. Również: W. Adamczyk, op. cit., s. 205. 
an der Fulda. Tam również w miesiąc później został aresztowany i oddany do dyspozycji Gestapo w Kassel. Nadal więc przebywał w oflagu, ale już jako więzień polityczny pozostający w areszcie ochronnym. 26 kwietnia $1940 \mathrm{r}$. przewieziony został do obozu koncentracyjnego w Buchenwaldzie, gdzie przebywał do czerwca 1941 r.; jak utrzymuje Szymon Datner, „,nieomal cały ten czas spędził w osławionym bunkrze buchenwaldzkim pozostającym pod nadzorem jednego z największych oprawców spośród załogi obozowej, [Martina] Sommera. Był katowany i nieludzko torturowany"58. Wydaje się nie ulegać wątpliwości, że pobyt zarówno w jednym, jak i drugim miejscu związany był ze śledztwem w sprawie wydarzeń w Stopnicy. Kolejnym etapem było przewiezienie Kalabińskiego do więzienia w Radomiu, do dyspozycji tamtejszego szefa policji bezpieczeństwa i Sicherheitsdienst (SD) Fritza Liphardta. Jak wynika $\mathrm{z}$ akt radomskiego więzienia, dowódca 55. DP trafił tam 26 czerwca 1941 r. o godzinie 20.00, „przyprowadzony [--] przez Sich[erheits]pol[izei]" ${ }^{59}$. Dokument przyjęcia precyzuje, iż więzień przekazany został do „wydziału specjalnego” (Sonderabteilung) ${ }^{60}$.

Przewiezienie do Radomia jednoznacznie wskazuje na związek z incydentem stopnickim; właściwy miejscowo był tu właśnie policyjny sąd doraźny (Polizei-Standgericht) w będącym wówczas siedzibą władz dystryktu Radomiu. Datner twierdzi co prawda, że osadzenie płk. Kalabińskiego w tym akurat więzieniu pozostawało w związku z rzekomo wydanym przezeń we wrześniu 1939 r. rozkazem „rozstrzeliwania niemieckiej ludności cywilnej"61, jednak Przemsza-Zieliński słusznie zauważa, iż $\mathrm{w}$ takim razie zadbano by o sprowadzenie podsądnego do Katowic, gdzie urzędował rozpoznający podobne delikty sąd specjalny (Sondergericht $)^{62}$. Brak jednak jakichkolwiek akt czy to śledztwa, czy też sprawy, jaka zapewne odbyła się przed radomskim sądem policyjnym. Pewne jest jedynie, iż 15 sierpnia 1941 r. na więziennej karcie ewidencyjnej Kalabińskiego pojawił się lakoniczny zapis „Akta zamknięto”; bez wpisania

58 Sz. Datner, Zbrodnie Wehrmachtu na jeńcach armii regularnych $w$ II wojnie światowej, Warszawa 1964, s. 329. Zob. też: J. Przemsza-Zieliński, Jeden z tysiąca Zagłębiaków, s. 191-192.

59 AP w Radomiu (dalej: Radom), Więzienie w Radomiu, 5873, Karta St. Kalabińskiego z księgi więźniów, 28 VI 1941, k. 1.

${ }^{60}$ AP Radom, Więzienie w Radomiu, 5873, Potwierdzenie przyjęcia więźnia, 26 VI 1941, k. 3.

${ }^{61}$ Sz. Datner, op. cit., s. 330. W ślad za nim supozycję tę powtarza W. Steblik, op. cit., s. 424 (przyp. 48).

${ }^{62}$ J. Przemsza-Zieliński, Jeden z tysiąca Zagtębiaków, s. 194. Przed tamtejszym sądem toczyła się m.in. sprawa kpt. Mariana Tułaka z 73. pp, oskarżonego o rzekome zbrodnie popełnione w Katowicach w pierwszych dniach września. Zob. G. Bębnik, Wrzesień 1939 r. w Katowicach, Katowice 2012, s. 291. 
powodu, choć formularz przewidywał tego typu doprecyzowanie ${ }^{63}$. W tym samym dniu Liphardt podpisał rozkaz zwolnienia o następującej treści: „Aresztowanego b[yłego] polskiego pułkownika, dowódcę dywizji Kalabińskiego, Stanisława, urodzonego w dniu 13 listopada 1890 r. w Sosnowcu, należy dziś zwolnić z więzienia w Radomiu i przekazać do dyspozycji policji bezpieczeństwa" ${ }^{64}$. Przypuszcza się, że były dowódca 55. DP został następnie stracony w egzekucji na tzw. Firleju ${ }^{65}$.

Nie był on przy tym, jak się okazuje, jedynym osadzonym w Radomiu żołnierzem tej dywizji. 27 listopada 1941 r. do miejscowego więzienia przewieziono z Warszawy trzech wymienionych wcześniej w policyjnym dzienniku żołnierzy kompanii ON „Mikołów” (Stanisława Pajonka vel Pająka, Stanisława Stachowiaka oraz Bernarda Kmiecika), osadzanych w październiku 1939 r. w obozie przejściowym w Sośnicy. Zaryzykować można przypuszczenie, iż stamtąd przewiezieni zostali najpewniej do obozu jenieckiego w Amtitz (obecnie Gębice) ${ }^{66}$, później do Torunia ${ }^{67}$, by przez łódzkie więzienie policyjne w Radogoszczy oraz Pawiak trafić następnie do Radomia ${ }^{68}$. Wszyscy trzej 20 stycznia 1941 r. przekazani zostali stamtąd do dyspozycji Liphardta ${ }^{69}$.

${ }^{63}$ AP Radom, Więzienie w Radomiu, 5873, Karta St. Kalabińskiego z księgi więźniów, 28 VI 1941, k. 1.

${ }^{64}$ AP Radom, Więzienie w Radomiu, 5873, Rozkaz zwolnienia St. Kalabińskiego, 15 VIII 1941, „Der festgenommene ehem[alige] polnischen [sic!] Oberst, Divisionskommandeur Kalabinski, Stanislaw geboren am 13.11.1890 in Sosnowice, ist heute aus dem Gefängnis Radom zu entlassen und der Sicherheitspolizei zu überstellen”, k. 4.

${ }^{65}$ Zob. J. Przemsza-Zieliński, Jeden z tysiąca Zagłębiaków, s. 194. Również: S. Piątkowski, Więzienie niemieckie w Radomiu 1939-1945, Lublin 2009, s. 114.

${ }^{66}$ Wskazuje na to zeznanie Władysława Świderskiego, który wraz ze Stachowiakiem przebywać miał w obozie w Amtitz od listopada do grudnia 1939 r. AIPN Ka, IPN Ka 564/348, Protokół rozprawy głównej, 27 VIII 1947, k. 89v. W przypadku Stachowiaka pojawia się także opinia, jakoby pewien czas spędził on również w więzieniu w Gliwicach. AIPN Ka, IPN Ka 564/348, Protokół rozprawy głównej (fragment zeznań Rozalii Gawędy), 19 VI 1947, k. 90v.

67 Podczas rozprawy głównej mieszkaniec Mikołowa Jan Sędziak zeznawał m.in.: „W grudniu 1939 r. siedziałem w jednej sali w więzieniu w Toruniu - razem ze Stachowiakiem, Kmiecikiem i Pająkiem, członkami Mikołowskiej Kompanii Obrony Narodowej”, AIPN Ka, IPN Ka 564/348, Protokół rozprawy głównej, 19 VI 1947, k. 90v.

68 AP Radom, Więzienie w Radomiu, 4864, Karta B. Kmiecika z księgi więźniów, 27 XI 1941, k. 1; ibidem, Zaświadczenie o badaniu lekarskim w więzieniu w Radogoszczy, 7 XI 1941, k. 3; ibidem, Karta zdrowia z więzienia Warszawa-Dzielna (Pawiak), 8 XI 1941, k. 5. Identyczne dokumenty, z takimi samymi datami sporządzone zostały dla St. Pajaka oraz St. Stachowiaka.

${ }^{69}$ AP Radom, Więzienie w Radomiu, 11198, Pismo szefa policji bezpieczeństwa i SD w dystrykcie radomskim do administracji więzienia w Radomiu, 20 I 1942, k. 2. W piśmie tym wymieniono kolejno tylko trzy osoby: właśnie Stachowiaka, Pająka oraz Kmiecika. 
Prócz nich niemiecki aparat policyjno-sądowy uchwycił w swoje tryby dwóch innych jeszcze żołnierzy kompanii „Mikołów”, podejrzanych o udział w incydencie. Byli to: przewijający się już w zeznaniach Kłoska Paweł Mędrok vel Mendrok oraz Jan Franke ${ }^{70}$. Odnośnie do tego ostatniego zeznania złożyła już po wojnie wdowa po nim, Augustyna Franke:

Było to w roku 1939, kiedy mąż mój powrócił z wojska polskiego z końcem miesiąca września. Do domu jeszcze nie zdążył przyjść, gdy niemcy [sic!] już czekali na niego i z Rynku w Mikołowie został aresztowany, w Mikołowie na niemieckiej policji siedział jeden tydzień, następnie został wywieziony do Gliwic do tamtejszego więzienia, do męża przyjeżdżałam co tydzień z bielizną i wtedy mąż mój powiedział mi, że z więzienia już nie wyjdzie, ponieważ jest mocno obciążony przez Kłoska, który między innymi oświadczył: że mąż mój miał niemieckim żołnierzom będącym w polskiej niewoli oczy wybijać i uszy urzynać. W roku 1941 został wywieziony do Oświęcimia, gdzie po trzech dniach zmarł ${ }^{71}$.

Jak się wydaje, śledztwo dotyczące Frankego (oraz przypuszczalnie również Mendroka) potoczyło się z nieznanych nam dziś powodów odmiennym torem, aniżeli ich trzech przywołanych wcześniej towarzyszy broni. Zakładać można, że zasadnicze czynności - niewątpliwie przy udziale Gestapo - miały miejsce w gliwickim więzieniu. Natomiast nadal pozostaje zagadką miejsce procesu oraz ewentualny wyrok. Jednak drogi pięciu obciążanych w tej sprawie żołnierzy kompanii „Mikołów” miały się jeszcze ze sobą zbiec w sposób wykluczający wszelką koincydencję. Oto bowiem wszyscy: Stanisław Stachowiak, Paweł Mendrok, Stanisław Pająk, Bernard Kmiecik i Jan Franke 28 lutego 1941 r., w tym samym transporcie przybyli do obozu koncentracyjnego Auschwitz. Co więcej, otrzymali tam kolejne numery - od 10882 do $10886^{72}$. Założyć można,

70 W opinii wystawionej Kłoskowi na wniosek prokuratora czytamy: „Po powrocie z tej wojny przysłużył się on dobrze niemcom [sic!], bowiem zeznawał obciążająco przed gestapo niemieckim na swoich własnych kolegów z mikołowskiej kompanii Obrony Narodowej, jak Mendroka Pawła, Frankiego [sic!] Jana, Świderskiego [Franciszka], Pająka [Stanisława], Kmiecika [Bernarda] i Stachowiaka [Stanisława]. Wszyscy wymienieni po zaaresztowaniu przez gestapo niemiecki[e] zginęli", AIPN Ka, IPN Ka 564/348, Relacja rewirowego Paszka, dot. P. Kłoska, 6 VII 1946, k. 8.

${ }^{71}$ AIPN Ka, IPN Ka 564/348, Protokół przesłuchania świadka A. Franke, 3 VIII 1946, k. 13v. Zeznania dotyczące P. Mendroka nie pozwalają na odtworzenie jego więzienno-obozowej drogi, poza osadzeniem w mikołowskim areszcie policyjnym. Zob. ibidem, Protokół przesłuchania świadka Konstantyny Mędrak [sic!], 3 VIII 1946, k. 10v.

72 http://auschwitz.org/muzeum/informacja-o-wiezniach/ (dostęp $30 \mathrm{~V}$ 2017). Numer 10881 należy do Srula Izraela Rotgäbera, ur. 7 lipca 1918 r. w Żarnowcu, 10887 zaś - do rolnika Franciszka Głodka, ur. 8 września 1883 r. w Wilczkowicach, ibidem. 
Tabela 2. Żołnierze 55. DP, którzy ponieśli śmierć w związku z „incydentem” w Stopnicy

\begin{tabular}{|c|c|c|c|c|c|}
\hline $\begin{array}{l}\text { Nazwisko } \\
\text { i imię }\end{array}$ & $\begin{array}{c}\text { Stopień } \\
\text { wojskowy }\end{array}$ & $\begin{array}{l}\text { Data i miejsce } \\
\text { urodzenia }\end{array}$ & $\begin{array}{c}\text { Data i miejsce } \\
\text { śmierci }\end{array}$ & $\begin{array}{c}\text { Ostatnie } \\
\text { miejsce } \\
\text { zamieszkania }\end{array}$ & $\begin{array}{l}\text { Ostatni przydział } \\
\text { słuźbowy }\end{array}$ \\
\hline $\begin{array}{l}\text { Kalabiński } \\
\text { Stanisław }\end{array}$ & $\mathrm{płk}$ & $\begin{array}{l}15 \text { XI 1890, } \\
\text { Sosnowiec }\end{array}$ & $\begin{array}{l}\text { po } 15 \text { VIII } \\
\text { 1941, Radom }\end{array}$ & Warszawa & dowódca 55. DP \\
\hline $\begin{array}{l}\text { Franke } \\
\text { Jan }\end{array}$ & kpr. & $\begin{array}{l}9 \text { IV 1903, } \\
\text { Mikołów }\end{array}$ & $\begin{array}{l}\text { po } 28 \text { II } 1941 \text {, } \\
\text { obóz konc. } \\
\text { Auschwitz }\end{array}$ & Mikołów & $\begin{array}{l}\text { dowódca drużyny } \\
\text { w kompanii } \\
\text { ON „Mikołów” } \\
(1 / 201 . p p, 55 . \text { DP) }\end{array}$ \\
\hline $\begin{array}{l}\text { Kmiecik } \\
\text { Bernard }\end{array}$ & szer. & $\begin{array}{l}10 \text { VII 1911, } \\
\text { Katowice-Dąb }\end{array}$ & $\begin{array}{l}\text { po } 28 \text { II } 1941 \text {, } \\
\text { obóz konc. } \\
\text { Auschwitz }\end{array}$ & Mikołów & $\begin{array}{l}\text { żołnierz kompanii } \\
\text { ON „Mikołów” } \\
\text { (1/201. pp, 55. DP) }\end{array}$ \\
\hline $\begin{array}{l}\text { Mendrok } \\
\text { vel Mędrok } \\
\text { Paweł }\end{array}$ & kpr. (?) & $\begin{array}{l}13 \text { V 1913, } \\
\text { Mikołów }\end{array}$ & $\begin{array}{l}\text { po } 28 \text { II } 1941 \text {, } \\
\text { obóz konc. } \\
\text { Auschwitz }\end{array}$ & Mikołów & $\begin{array}{l}\text { prawdopodobnie } \\
\text { dowódca drużyny } \\
\text { w kompanii } \\
\text { ON „Mikołów” } \\
\text { (1/201.pp, 55. DP) }\end{array}$ \\
\hline $\begin{array}{l}\text { Pająk vel } \\
\text { Pajonk } \\
\text { Stanisław }\end{array}$ & szer. & $\begin{array}{l}27 \text { lub } 28 \text { IV } \\
\text { 1913, Mikołów }\end{array}$ & $\begin{array}{l}\text { po } 28 \text { II 1941, } \\
\text { obóz konc. } \\
\text { Auschwitz }\end{array}$ & Mikołów & $\begin{array}{l}\text { żołnierz kompanii } \\
\text { ON „Mikołów” } \\
(1 / 201 . p p, 55 . D P)\end{array}$ \\
\hline $\begin{array}{l}\text { Stachowiak } \\
\text { Stanisław }\end{array}$ & kpr. (?) & $\begin{array}{l}12 \text { IV 1914, } \\
\text { Chrząstowo } \\
\text { (pow. Śrem) }\end{array}$ & $\begin{array}{l}\text { po } 28 \text { II 1941, } \\
\text { obóz konc. } \\
\text { Auschwitz }\end{array}$ & Mikołów & $\begin{array}{l}\text { prawdopodobnie } \\
\text { dowódca drużyny } \\
\text { w kompanii } \\
\text { ON „Mikołów” } \\
\text { (1/201. pp, 55. DP) }\end{array}$ \\
\hline $\begin{array}{l}\text { Świderski } \\
\text { Franciszek }\end{array}$ & kpr. & $\begin{array}{l}27 \text { I 1903, } \\
\text { Mrowino } \\
\text { (pow. Poznań) }\end{array}$ & $\begin{array}{l}18 \text { X 1939, } \\
\text { Mikołów (cela } \\
\text { więzienia } \\
\text { sądowego) }\end{array}$ & Mikołów & $\begin{array}{l}\text { dowódca plutonu } \\
\text { w kompanii } \\
\text { ON „Mikołów” } \\
\text { (1/201. pp, 55. DP) }\end{array}$ \\
\hline
\end{tabular}

Źródło: AP Radom, Więzienie w Radomiu; AIPN Ka, IPN Ka 564/348; BAMA Freiburg, RW 2-48, k. 131-145; Miejsce Pamięci i Muzeum Auschwitz-Birkenau. Były niemiecki nazistowski obóz koncentracyjny i zagłady (http://auschwitz.org/muzeum/informacja-o-wiezniach); J. Przemsza-Zieliński, Jeden z tysiąca Zagłębiaków. Rzecz o pułkowniku Stanisławie Kalabińskim, ostatnim dowódcy śląsko-dąbrowskiej Obrony Narodowej, Sosnowiec 1998.

że jako wykonawcy wydanych przez przełożonego rozkazów, co być może w oczach niemieckich sędziów okazało się okolicznością łagodzącą, skazani mogli zostać ,jedynie” na karę pobytu w obozie i w takim charakterze

Zakładać można zatem, że grupa pięciu żołnierzy nie była zestawiona w sposób przypadkowy; obejmowała też najpewniej (wyjąwszy płk. Kalabińskiego) wszystkich skazanych za udział w stopnickim incydencie. 
osadzeni w Auschwitz. Niezależnie od tego, szans na przeżycie nie mieli niemal żadnych.

Mamy zatem do czynienia z sytuacją nader oryginalną: odpowiedzialnością za domniemaną egzekucję obciążeni zostają jej bezpośredni wykonawcy, następnie dowodzący batalionem kpt. Blew oraz - dowódca dywizji, płk Kalabiński. Czym wytłumaczyć widoczne tu luki w rozkazodawczej hierarchii? Pytanie to zadawać musiał sobie również i Przemsza-Zieliński, jednak udzieloną przezeń odpowiedź trudno uznać za zadowalającą. Zamykając swe rozważania nad odpowiedzialnością płk. Kalabińskiego za stopnicki „incydent” napisał bowiem: „Wynika więc z powyższego, iż śledztwo nie było zbyt drobiazgowe i że Niemcom bynajmniej nie chodziło o wyjaśnienie szczegółów owego incydentu i dojście do obiektywnej prawdy"73. O co zatem chodziło? Również i tu nie ma sosnowiecki historyk żadnych wątpliwości, konkludując, iż wszystko to służyć miało temu, „aby pozbyć się jednego z wybitnych polskich dowódców, a także rzucić cień na polskich obrońców Śląska"74. Zatem - klasyczna zbrodnia sądowa.

„Wytypowanie” w charakterze kozła ofiarnego za stopnicki „incydent" właśnie płk. Kalabińskiego wiąże Przemsza-Zieliński z pochodzącym z grudnia 1939 r. dokumentem Abwehry, opublikowanym swego czasu przez Stefana Jellentę ${ }^{75}$. Jest to pismo przewodnie, do którego załączono - zaginiony niestety - opis całego incydentu. Korespondencja ta stanowiła dla Przemszy-Zielińskiego koronny dowód „dziwnej niekonsekwencji Niemców"76 i przyświecających im zamiarów, które Jellenta z kolei precyzuje jako „wywołanie negatywnego nastawienia oficerów i żołnierzy niemieckich do oficerów i żołnierzy WP, z którymi mogliby się zetknąć jako z jeńcami"77; służyć miało temu także przesłanie jej do wiadomości licznym jednostkom i instytucjom. Doprawdy? W istocie treść tego pisma jest następująca (tłumaczenie S. Jellenty):

Dot. zastrzelenie żołnierzy niemieckich w Stopnicy.

W załączeniu przekazuje się opis incydentu, z którego wynika, że pułkownik armii polskiej, Kalabiński, dowódca 55. DP, stoi pod zarzutem, iż zastrzelono żołnierzy orkiestry niemieckiego 15. pułku czołgów.

Poszukiwania wykazały, że płk Kalabiński znajduje się od 25.11. [sic!] br. w oflagu IX C w Rothenburgu nad Fuldą.

${ }^{73}$ J. Przemsza-Zieliński, Jeden z tysiąca Zagłębiaków, s. 197.

74 Ibidem, s. 197.

75 S. Jellenta, Jeszcze jeden dokument zbrodni Wehrmachtu, „Wojskowy Przegląd Historyczny" 13, 1968, 2, s. 397-399.

${ }^{76}$ J. Przemsza-Zieliński, Jeden z tysiąca Zagłębiaków, s. 195.

77 S. Jellenta, op. cit., s. 399 (przyp. 9). 
Uprasza się o spowodowanie dalszych kroków - celem oddania obwinionego pod sąd i ukarania. Uprasza się o powiadomienie we właściwym czasie o wyniku całej sprawy.

$\mathrm{Z}$ rozkazu - [Leopold] Bürkner ${ }^{78}$.

Przytoczony przez Jellentę rozdzielnik, traktowany przezeń jako koronny dowód na zamiar „wywołania negatywnego nastawienia”, nie jest jednak niczym osobliwym; bywały one daleko obszerniejsze i wywodzenie $z$ tego jakichś szczególnych intencji jest myśleniem raczej życzeniowym. Istotniejsze są konstatacje, jakie czyni w związku z tym Przemsza-Zieliński. A są one ważkie; nie tyle może dla wyjaśnienia okoliczności samego „incydentu”, co raczej zilustrowania niefrasobliwości, z jaką podszedł ten autor do oskarżenia wysuwanego pod adresem oficera, wobec którego nie kryje on nie tyle nawet sympatii, co wręcz uwielbienia ${ }^{79}$. Wywodzi wprawdzie Przemsza-Zieliński, iż „dowódca odpowiada za czyny swoich żołnierzy", po czym jednak dodaje:

Pedanteria niemiecka winna była więc skłonić oficerów śledczych, aby przesłuchali w tej sprawie przełożonych oskarżonego oficera. Zarówno gen. Szylling, jak i gen. Sadowski byli w tym czasie w dyspozycji Niemców przebywali bowiem w obozach oficerskich (oflagach). Ani jeden, ani drugi $\mathrm{w}$ tej sprawie nie byli jednak indagowani i w ogóle nawet nie poinformowani (obaj pozostawili wspomnienia, w których niewątpliwie odnotowaliby ten fakt); obaj dowiedzieli się o całej sprawie dopiero po wojnie ${ }^{80}$.

Rewelacji tych nie opatruje autor jakimkolwiek przypisem, stąd też trudno dociec, czy swoją pewność opiera na podstawach trwalszych, aniżeli własne domysły. A gdyby przyjąć, że obydwaj generałowie pewnych spraw najzwyczajniej nie chcieli poruszać? I dalej:

78 Ibidem, s. 398.

79 Powody napisania książki wyłuszcza Przemsza-Zieliński zarówno w dedykacji, jak i w jednoznacznie zatytułowanym pierwszym rozdziale („Zagłębie i Sosnowiec mogą być z niego dumne..."). Rezygnując z przytaczania zawartych tam tez, zacytować można treść banderoli, jaką opatrywana była książka w punktach sprzedaży: „Płk Stanisław Kalabiński - to człowiek, po którym w Zagłębiu Dąbrowskim powinno pozostać coś więcej niż pamięć najbliższych. Kupując tę książkę bierzesz też udział w akcji społecznej toczonej przez ludzi dobrej woli, aby pośmiertnie mianowano go generałem Wojska Polskiego, a imię jego nadano jednej z sosnowieckich ulic i jednemu z nowo powstających gimnazjów. Przeczytaj tę monografię jednego z najwybitniejszych synów Zagłębia Dąbrowskiego i poprzyj naszą akcję", J. Przemsza-Zieliński, Jeden z tysiąca Zagłębiaków, s. 4-9 oraz banderola.

${ }^{80}$ Ibidem, s. 196-197. 
Gdyby śledztwo było prowadzone istotnie drobiazgowo, to oficerowie śledczy, na podstawie wiadomości zdobytych przez niemiecki wywiad, doszliby także do wiedzy na temat konkretnego polskiego oddziału, który „dopuścił się" tej „zbrodni” (batalion ON „Sosnowiec” lub batalion ON „Katowice”) i do nazwiska dowódcy średniego szczebla, a więc ppłk. Władysława Adamczyka - dowódcy 201. pp rez. W pierwszym rzędzie bowiem restrykcje co do złamania zasad konwencji genewskiej spaść musiałyby na bezpośrednich dowódców batalionów, a więc kpt. Pawła Staszkiewicza i kpt. Pawła Blewa (ten ostatni wszakże już nie żył), a już na pewno na dowódcę pułku. Nic takiego jednak nie nastąpiło. Płk W. Adamczyk, będący także w niewoli niemieckiej, również nigdy na ten temat nie był nawet indagowany, a o sprawie - co wynika z jego drukowanych wspomnień - dowiedział się też dopiero po wojnie ${ }^{81}$.

W konfrontacji z przytoczonymi wyżej dokumentami pierwszy zarzut (ten z „dojściem do wiedzy”) wzbudzić może jedynie zażenowanie. To raczej Przemsza-Zieliński na podstawie szczątkowych przesłanek stawia ostro zdefiniowane tezy, by je następnie w efektowny sposób obalić. Wiemy wszak, że najpóźniej w październiku 1939 r. wiedza taka była już Niemcom dostępna, a znajomość personaliów sięgała poziomu zwykłych szeregowych. Pozostawienie w spokoju ppłk. Adamczyka oraz kpt. Wikarskiego nie mogło być zatem efektem imputowanej przez Przemszę-Zielińskiego „niekonsekwencji” lub braku „drobiazgowości” i jest przy tym, w świetle przytoczonych dokumentów, z gruntu wytłumaczalne. To płk Kalabiński, o czym zaświadcza por. Jabłoński, bezpośrednio i z pominięciem dowódcy pułku wydał rozkaz egzekucji ${ }^{82}$; w zestawieniu z zeznaniem

81 Ibidem, s. 196.

82 Brak jakichkolwiek sankcji wobec dowódcy pułku mógł również wypływać z innych jeszcze przesłanek. Dysponujemy spisaną przez pszczyńskiego historyka Janusza Ryta relacją, którą ten usłyszał z ust Aleksandra Bukki, we wrześniu 1939 r. podporucznika, dowódcy plutonu w batalionie ON „Oświęcim” 201. pp. Brzmi ona: „Płk Kalabiński telefonicznie polecił ppłk. Adamczykowi, by 201. pp nocnym marszem pokonał dużą odległość, kierując się na wschód. Adamczyk wysunął tu zastrzeżenia twierdząc, że przy towarzyszącej mu sporej grupie jeńców nienawykłych do maszerowania nie będzie w stanie posuwać się w takim tempie, na co Kalabiński zareagował słowami: «Nie wiesz, co masz zrobić? Rozwal ich!» Odpowiedź Adamczyka brzmiała: «A sam ich sobie rozwalaj!» Następnie pod eskortą odesłał jeńców do sztabu dywizji. Mówiono potem, że wśród jeńców byli dwujęzyczni Ślązacy i oni po drodze rozmawiali z konwojentami, którzy im wprost oświadczyli, że prowadzą ich do dowódcy, który kazał ich rozstrzelać i żeby uciekali. Konwojenci wypuścili Ślązaków, zaś resztę rozstrzelali, a ciała spalili w stodole (choć krążyły też pogłoski, że jeńców spalono żywcem). Niemcy jeszcze we wrześniu podczas późniejszych działań bojowych zaczęli wypytywać o płk. Kalabińskiego w każdej większej grupie wziętych do niewoli jeńców, o czym szybko donieśli do sztabu zbiegli z niemieckiej niewoli nasi żołnierze", Relacja ustna A. Bukki z 14 X 1999, 
Kłoska („d[owód]ca batalionu [kpt. Blew] wysłał kapr[ala] Świderskiego z kilku ludźmi”) lub zgoła zapisem z policyjnego dziennika („zadanie takie otrzymali od polskiego majora [nazwiskiem] Pleff") wydaje się również jasne, dlaczego z całej sprawy obronną ręką wyszedł także kpt. Wikarski. Trudno sobie jednak wyobrazić, by obydwaj oficerowie nie zostali przesłuchani w trakcie toczącego się przeciwko płk. Kalabińskiemu śledztwa; odpowiednie zapisy nie są jednak znane. A szkoda, bo za ich sprawą zniknęłaby znakomita większość obecnych jeszcze w tej sprawie znaków zapytania. Na pewno jednak oczywiste pozostają powody, dla których wszyscy uwikłani w ów „incydent” oficerowie (poza Aleksandrem Bukką, który jednak nie zdecydował się na nadanie swym rewelacjom formy pisemnej) do końca życia zachowali milczenie.

\section{Propagandowe nagłośnienie incydentu}

Wysiłek, jaki niemieckie władze włożyły w wyjaśnienie całego incydentu, nie przełożył się jednak, co samo w sobie zadziwiające, na jego propagandową eksploatację. Zaledwie w jednej okolicznościowej publikacji (choć zarazem takiej, która do 1945 r. doczekała się przynajmniej sześciu wydań) odnaleźć udało się - najdosłowniej - ślad tego wydarzenia, jakby stworzonego do potwierdzania pewnych propagandowych klisz. Mowa o dziele Hannsa Wiedemanna Wir zogen gegen Polen: „Cel obydwu dywizji: most przez Wisłę pod Baranowem, jakieś $40 \mathrm{~km}$ na północny wschód od Szczucina. W tym dniu pod Rytwianami, gdzie radość ze zwycięstwa przytłumiona jest faktem odnalezienia w Stopnicy zwłok wymordowanej przez Polaków w okrutny sposób orkiestry, szwabska dywizja [27. DP] skręca na północny wschód"83.

I tyle. Nieodparcie wypływa stąd konkluzja, iż trudno uznać stopnicki „incydent” (a w ślad za nim również przypadek płk. Kalabińskiego) za

spisana i przekazana przez J. Ryta (Pszczyna). A. Bukko stał wówczas na czele plutonu asystencyjnego dowódcy 201. pp, stąd też niemal stale przebywał przy ppłk. Adamczyku. Zauważmy, że opis ten dotyczy innych jeńców, aniżeli członkowie orkiestry. W relacji, jaką Bukko zamieścił w 1984 r. na łamach regionalnej prasy, próżno jednak doszukiwać się podobnej szczerości. Zob. A. Bukko, Od Suszca do Suśca (zapiski dowódcy plutonu). Wrześniowy szlak bojowy kompanii „Pszczyna”, „Echo” 19 IX 1984.

83 „Ziel beider Divisionen ist also: die Weichselbrücke bei Baranow, etwa 40 Kilometer nordostwärts von Szczucin. An dem Tage von Rytwiany, dessen Siegesfreude freilich durch die Auffindung der Toten eines von den Polen grausam ermordeten $\mathrm{Mu}-$ sikkorps in Stopnica getrübt wurde, biegt die schwäbische Division nach Nordosten aus", H. Wiedemann, Wir zogen gegen Polen. Kriegserinnerungswerk des VII Armeekorps, wyd. 6, München [po 1940], s. 26. 
element zaaranżowanej przez Niemców propagandowej ofensywy, skoro jego nagłośnienie było raczej mizerne ${ }^{84}$.

Paradoksalnie, w Niemczech znacznie więcej uwagi poświęcono Stopnicy dopiero w powojennych publikacjach. Mowa oczywiście o tych powstałych w Niemczech Zachodnich; w wydanej w 1976 r. historii 15. ppanc „incydentowi” w Stopnicy poświęcony został już znacznie obszerniejszy fragment:

Ponieważ podczas kampanii w Polsce w szybkim tempie dążono naprzód, dowódca pułku postrzegał prowadzenie z sobą stosunkowo licznej orkiestry pułkowej jako obciążenie [--]. Pułkownik [Johannes] Streich wysłał ją wobec tego wraz z jej autobusem z powrotem do domu, udzieliwszy jej przy tym wyraźnego nakazu, by powrotną drogę odbyła tą samą trasą, co wcześniej. Niestety, orkiestra zboczyła jednak z nakazanej drogi i 10 września 1939 r. natknęła się pod Stopnicą na rozproszone polskie oddziały, których ostrzał spowodował pożar autobusu. Ci, którzy ocaleli, zostali zamknięci w stodole położonej 800 metrów na wschód od Stopnicy, którą to Polacy następnie podpalili. Polacy, gęsto obstawiwszy stodołę, udaremniali próby ucieczki w ten sposób, że na miejscu kładli strzałami z broni palnej każdego, kto tylko próbował uniknąć okrutnej śmierci w płomieniach. Pomimo tego dwóm spośród szesnastu zamkniętych w stodole ludzi udało się ujść z tego piekła. Jeden z nich, podoficer Markart, nie uszedł jednak daleko. Przez inny niemiecki oddział znaleziony został on niedaleko stodoły, z postrzałem w tył głowy oraz łącznie dwudziestoma ranami od bagnetów. Udało się ujść jedynie feldfeblowi Rösnerowi, który wkrótce potem, przebrany w cywilne ubranie natknął się na niemieckie oddziały i dzięki któremu 15. pułk pancerny dowiedział się o tragicznym losie swej orkiestry ${ }^{85}$.

${ }^{84}$ Już po oddaniu niniejszego artykułu do recenzji w ręce autora trafiła wydana najpewniej jeszcze w 1939 r. propagandowa broszura Polnische Blutschuld, traktująca zasadniczo o tzw. bydgoskiej krwawej niedzieli. Znalazł się tam jednak również fragment poświęcony Stopnicy: „Der Gefangenenmord Stopnica, der durch Zeugenaussagen von sechs überlebenden deutschen Soldaten belegt ist, zeigt, welches Schicksal die vermißten deutschen Soldaten erlitten haben mögen", następnie zamieszczone zostały faksymile cytowanych tu zeznań H. Schloerba, Polnische Blutschuld, b.m.w. [ok. 1939], b.pag.

85 „Als es mit dem Vormarsch in Polen zügig vorwärts ging, wurde seitens des Regiments-Kommandeurs die Mitführung der zahlenmäßig doch immerhin starken Regiments-Kapelle nur als eine zusätzliche Belastung des Nachschubs angesehen [- - ]. Oberst Streich schickte sie darum in ihrem Omnibus in die Heimat zurück und erteilte ihr dabei die ausdrückliche Weisung, auf dem bisherigen Vormarschweg zurückzufahren. Das Musikkorps wich aber leider vom vorgeschriebenen Weg und geriet am 10. September 1939 bei Stobnica [sic!] an versprengte polnische Truppen, die den Omnibus in Brand schossen. Die Überlebenden jenes Überfalls wurden daraufhin in eine Scheune, 800 Meter ostwärts von Stobnica gesperrt, welche die Polen anschließend 
W podobny sposób, acz nieco zwięźlej wydarzenie to przedstawione zostało w monografii 5. DPanc., pióra jej byłego oficera, Antona Detleva von Plato:

W ciągu dnia nadchodzi wiadomość, stawiająca na nogi całą dywizję: w Stopnicy podstępnie wymordowana została orkiestra 15. pułku pancernego. Orkiestra ta, wraz ze swoim autobusem została przez pułkownika Streicha 9 września odkomenderowana z powrotem ze Staszowa przez Chmielnik do Pińczowa, celem pomniejszenia znajdujących się na przedzie taborów. Nieszczęśliwym trafem autobus zbłądził w kierunku Stopnicy, gdzie orkiestra wzięta została do niewoli i zamknięta w stodole. Stodoła została podpalona, a każdy, kto pragnął uciec, został zastrzelony. Jedynie trzech ludzi zdołało zbiec i dotrzeć do niemieckich liniii ${ }^{86}$.

Tym, co w dwóch ostatnich tekstach szczególnie uderzające, jest oczywiście scena spalenia żywcem zamkniętych w stodole jeńców, dotychczas marginalnie obecna jedynie w późnej relacji Bukki. W dwa lata po ukazaniu się książki von Plato stopnicki ,incydent” raz jeszcze pojawił się w podobnego rodzaju literaturze. Tym razem była to obszerna monografia 7. pp, pióra Romualda Bergnera:

Po południu 9 września orkiestra wojskowa 15. p[ułku] panc[ernego] (11.DPanc), podczas podróży do rodzinnej miejscowości, widocznie z powodu zboczenia z właściwej drogi, dostaje się w Stopnicy do nieprzyjacielskiej

anzündeten. Ausbruchsversuchen begegneten die Polen, welche die Scheune dicht umstanden, auf die Art, daß sie einen jeden elendig zusammenschossen, der dem grausamen Flammentod entkommen wollte. Dennoch schafften es von den 16 in die Scheune Gesperrten 2 Mann, diesem Inferno zu entkommen. Einer der beiden, Uffz. Markart, kam allerdings nicht weit. Er wurde hinterher mit einem Kopfschuß und mit insgesamt 20 Bajonettstichen unweit der Scheune von einer anderen deutschen Einheit gefunden. Allein Feldwebel Rösner gelang es zu entkommen, der wenig später in Zivil verkleidet auf deutsche Verbände stieß und durch den das Pz. Rgt. 15 Kenntnis jenes Opferganges der Regiments-Musik erhielt.", G.W. Schrodek, Ihr Glaube galt dem Vaterland. Geschichte des Panzer-Regiments 15 (11. Panzer-Division), München 1976, s. 62-63. Po kampanii francuskiej 1940 r. 15. ppanc przeniesiony został do nowoutworzonej 11. DPanc.

${ }^{86}$ „Im Laufe des Tages kommt die Nachricht, die die gesamte Division schwer erregt: Das Musikkorps des Pz. Rgt. 15 wurde in Stopnica heimtückisch ermordet. Das Musikorps war am 9. September von Oberst Streich mit seinem Omnibus von Staszow über Chmielnik nach Pinczow zurückgeschickt worden, um den Troß vorne möglichst zu verringern. Unglücklicherweise verfuhr sich der Omnibus in Richtung Stopnica, wo das Musikkorps gefangengenommen und in eine Scheune gesperrt wurde. Die Scheune wurde angezündet, jeder, der entfliehen wollte, wurde erschossen. Nur drei Mann konnten entkommen und die deutsche Linie erreichen", A.D. von Plato, Die Geschichte der 5. Panzerdivision 1938-1945, Regensburg 1978, s. 26. 
niewoli. Rozbrojeni żołnierze zostają na rozkaz polskiego oficera spędzeni razem z innymi niemieckimi jeńcami i we wczesnych godzinach wieczornych w pobliżu Stopnicy podstępnie rozstrzelani. Tylko niewielkiej części udaje się zbiec i dotrzeć do niemieckich liniii ${ }^{87}$.

Jak widać, tym razem opis całej sytuacji jest co najmniej zbliżony do tego, co wyłania się z dotychczasowych ustaleń. Trudno jednak powiedzieć, czy Bergner korzystał z dodatkowych informacji, czy też po prostu w krytyczny sposób podszedł do twórczości swych kolegów.

\section{Podsumowanie}

Mimo sygnalizowanych braków źródłowych wydaje się, że powyższe dociekania zamknąć można kilkoma wnioskami. Wciąż mając zatem na uwadze publikację Przemszy-Zielińskiego, zakwestionować można niemalże całość jego ustaleń (abstrahując od faktu, że w wielu punktach stanowią one powtórzenie wcześniejszych opinii innych autorów). I tak: niemieckie śledztwo nie dotyczyło żołnierzy orkiestry 15. ppanc poległych w walce w Stopnicy, lecz tych, którzy wzięci przy tej okazji do niewoli mieli zostać (wraz z jeńcami z innych jednostek) rozstrzelani poza samą miejscowością. Po drugie, śledztwo to było na tyle drobiazgowe, że pozwoliło ustalić personalia przynajmniej kilku najbardziej zaangażowanych w ów incydent żołnierzy, następnie zaś na odnalezienie ich i aresztowanie. Po trzecie, przy tej też najpewniej okazji ustalono, że rozkaz egzekucji wyszedł bezpośrednio od dowódcy dywizji, płk. Kalabińskiego, wcielił go zaś w życie dowódca 1 batalionu 201. pp kpt. Blew; inaczej trudno wytłumaczyć, dlaczego do odpowiedzialności nie zostali pociągnięci dowódca kompanii oraz pułku. W przypadku tego drugiego realna wydaje się możliwość odmowy wykonania przezeń stosownego rozkazu, o czym świadczyłaby zarówno relacja Bukki, jak i logika wypadków.

87 „Am Nachmittag des 9. September geriet das Musikkorps des Pz. Rgt. 15 (11. PD) auf der Fahrt in den Heimatort, offenbar durch Abkommen von der richtigen Marschstraße, in Stopnica in feindliche Gefangenschaft. Die entwaffneten Soldaten werden zusammen mit anderen deutschen Gefangenen auf Befehl eines polnischen Offiziers zusammengetrieben und in den frühen Abendstunden in der Nähe von Stopnica meuchlings erschossen. Nur einem kleinen Teil gelingt es zu entkommen und die deutschen Linien zu erreichen", R. Bergner, Schlesische Infanterie. Grenadier-Regiment 7, das Infanterie-Regiment 7 und seine Stamm-Truppenteile in Krieg und Frieden. Eine Chronik schlesischer Infanterie 1808-1945, Bochum 1980, s. 46. W tekście widoczna omyłka co do ówczesnej przynależności 15. ppanc. 
Tak czy inaczej, dalsze negowanie faktu egzekucji niemieckich jeńców pod Stopnicą 9 września 1939 r. nie wydaje się możliwe.

$\mathrm{Na}$ zakończenie nie sposób jednak oprzeć się pewnej refleksji. Otóż wyjaśniając okoliczności stopnickiego „incydentu”, uruchomili Niemcy niemalże wszelkie możliwe służby, tak wojskowe, jak i policyjne, przeprowadzając regularne, skoncentrowane na wyświetleniu najdrobniejszych nawet okoliczności śledztwo. Tymczasem próżno szukać zbliżonej choćby rzetelności w przypadku nieporównanie liczniejszych zbrodni wojennych, jakich w trakcie kampanii 1939 r. dopuszczali się żołnierze Wehrmachtu czy SS. Przedstawiony tu przypadek różnicę tę dodatkowo jeszcze wyostrza.

\section{Streszczenie}

Wycofujące się z województwa śląskiego na wschód oddziały Armii „Kraków” 9 września 1939 r. dotarły do miasteczka Stopnica. Obronę tego punktu powierzono 201. pułkowi piechoty z 55. Dywizji Piechoty, dowodzonej przez płk. Stanisława Kalabińskiego. Pułkowi towarzyszyli niemieccy jeńcy, zarówno wzięci do niewoli wcześniej, jak i dopiero w samej Stopnicy. Ci drudzy rekrutowali się z orkiestry wojskowej 15. pułku pancernego (5. Dywizja Pancerna).

W artykule rozważane są dalsze losy tych jeńców; strona niemiecka uznała bowiem, że zostali oni przez polskich konwojentów rozstrzelani, i to na rozkaz samego dowódcy dywizji. Rozkaz ten żołnierzom eskorty przekazany miał zostać przez dowódcę 1 batalionu, kpt. Pawła Blewa. Szeroko zakrojone śledztwo doprowadziło do uwięzienia kilku odpowiedzialnych za ten czyn żołnierzy, w tym także samego płk. Kalabińskiego. Został on najpewniej stracony, szeregowi zaś żołnierze osadzeni w obozie w Auschwitz, gdzie również ponieśli śmierć.

W polskiej literaturze powojennej stopnicki „incydent” traktowany jest jako zbrodnia sądowa, niemający rzeczywistych podstaw akt mordu na płk. Kalabińskim. Pogląd ten eksponuje zwłaszcza biograf pułkownika, Jan Przemsza-Zieliński.

Tymczasem na podstawie zarówno szczątkowych dokumentów niemieckiego śledztwa, jak i powojennych polskich dokumentów, a także i pośrednich niestety przekazów ustnych cały incydent nabiera innych kształtów, aniżeli zarysowane przez choćby Przemszę-Zielińskiego. Według wszelkiego prawdopodobieństwa egzekucja niemieckich jeńców naprawdę miała miejsce, co więcej - doszło do niej najpewniej faktycznie na rozkaz płk. Kalabińskiego.

\section{The "Incident" at Stopnica on 9 September 1939 Between a Court Crime and Execution}

Retreating from the Silesian Voivodeship to the east, on 9 September 1939, the units of the „Kraków” Army reached the town of Stopnica. The defence of the post was committed to the $201^{\text {st }}$ Infantry Regiment of the $55^{\text {th }}$ Infantry Division 
commanded by Col. Kalabiński. The regiment was accompanied by some POWs, taken both before Stopnica, and in the town itself. The latter were members of the military band of the $15^{\text {th }}$ Armoured Regiment ( $5^{\text {th }}$ Armoured Division).

The article presents the later fate of those prisoners; the Germans concluded that the POWs were shot by their Polish escorts, on the order of the division commander himself. The order was thought to be passed on by the commander of the First Battalion, Capt. Blew. A broad investigation led to the imprisonment of several soldiers responsible for the deed, including Col. Kalabiński himself. Most probably he was executed, and the privates were put in the camp at Auschwitz, where they were killed.

In the Polish post-war literature on the subject the incident of Stopnica is regarded as a court crime, that is, the unjustified murder of Col. Kalabiński. This view is especially advocated by the colonel's biographer, Jan Przemsza-Zieliński.

However, in the light of both the fragmentary documentation of the German investigation, and post-war Polish documents, as well as indirect oral testimonies, the incident takes on a totally different shape than that described by Przemsza-Zieliński. In all likelihood, the execution of the German POWs actually took place, and what is more - it was most probably carried out on Col. Kalabiński's order.

Translated by Grażyna Waluga

\section{Bibliografia}

Adamczyk Władysław, Przeciw nawale. Rok 1939. Pamiętnik dowódcy 201. pułku piechoty, Pax, Warszawa 1970.

Bergner Romuald, Schlesische Infanterie. Grenadier-Regiment 7, das Infanterie-Regiment

7 und seine Stamm-Truppenteile in Krieg und Frieden. Eine Chronik schlesischer Infanterie 1808-1945, Pöppinghaus, Bochum 1980.

Bębnik Grzegorz, Mikołów w początkach II wojny światowej, Miejska Biblioteka Publiczna w Mikołowie, Mikołów 2009.

Bębnik Grzegorz, Wrzesień 1939 r. w Katowicach, IPN Katowice, Katowice 2012.

Bukko Aleksander, Od Suszca do Suśca (zapiski dowódcy plutonu). Wrześniowy szlak bojowy kompanii „Pszczyna”, „Echo” 19 IX 1984.

Datner Szymon, Zbrodnie Wehrmachtu na jeńcach armii regularnych $w$ II wojnie światowej, MON, Warszawa 1964.

Jellenta Stefan, Jeszcze jeden dokument zbrodni Wehrmachtu, „Wojskowy Przegląd Historyczny" 13, 1968, 2, s. 397-399.

Piątkowski Sebastian, Więzienie niemieckie w Radomiu 1939-1945, IPN Lublin, Lublin 2009.

Plato Anton Detlev von, Die Geschichte der 5. Panzerdivision 1938-1945, Gemeinschaft der Angehörigen der ehemaligen 5. Panzerdivision, Regensburg 1978.

Polnische Blutschuld, b.m.w. [ok. 1939].

Przemsza-Zieliński Jan, Jeden z tysiąca Zagłębiaków. Rzecz o pułkowniku Stanisławie Kalabińskim, ostatnim dowódcy śląsko-dąbrowskiej Obrony Narodowej, Sosnowiecka Oficyna Wydawniczo-Autorska „Sowa-Press”, Sosnowiec 1998. 
Przemsza-Zieliński Jan, Księga wrześniowej chwały pułków śląskich, t. 2, Sosnowiecka Oficyna Wydawniczo-Autorska „Sowa-Press”, Katowice-Sosnowiec 1993.

Rzepecki Jan, Wspomnienia i przyczynki historyczne, Czytelnik, Warszawa 1983.

Schrodek Gustav W., Ihr Glaube galt dem Vaterland. Geschichte des Panzer-Regiments 15 (11. Panzer-Division), Schild-Verlag, München 1976.

Steblik Władysław, Armia „Kraków” 1939, MON, Warszawa 1975.

Szendzielarz Ryszard, Bromboszcz Bogusław, Mikołów z perspektywy 150 lat, Miejska Biblioteka Publiczna w Mikołowie, Mikołów 2009.

Wiedemann Hanns, Wir zogen gegen Polen. Kriegserinnerungswerk des VII Armeekorps, Zentralverlag der NSDAP, Franz Eher Nachf., München [po 1940].

Zayas Alfred-Maurice de, Die Wehrmacht-Untersuchungsstelle. Deutsche Ermittlungen über alliierte Völkerrechtsverletzungen im Zweiten Weltkrieg, Verlag Universitas Langen-Müller, Monachium 1979.

Biogram: Grzegorz Bębnik (ur. 1970), dr hab. nauk humanistycznych, pracownik Oddziałowego Biura Badań Historycznych IPN w Katowicach. Zajmuje się głównie problematyką II wojny światowej; kontakt: grzegorz.bebnik@ipn.gov.pl. 